\title{
Entre o lucro e a distinção. Uma aproximação ao significado de "ser elite" nas Minas Gerais oitocentistas
}

Between Profit and Distinction. An Inquiry on the Meaning of "being part of the elite" in 19th Century Minas Gerais

\section{Ana Rosa Cloclet da Silva} Professora de História na FACAMP - Faculdades de Campinas

\section{Resumo}

Sustentado por fontes de natureza cartorial - testamentos e inventários post mortem - o presente artigo visa reconstituir a composição das fortunas, estruturas produtivas e relações com a mão-de-obra, caracteristicas dos proprietários radicados nos Termos de Ouro Preto, São João Del Rei, Paracatu, assim como no Distrito Diamantino, entre 1792 e 1831. Focalizando a diversidade material e social da provincia mineira, durante um periodo caracterizado pelo fenômeno da "acomodação evolutiva" de sua economia, buscase ainda iluminar as diferentes condições e estratégias disponíveis àqueles homens que, visando o lucro, sem abrir mão da distinção, mostraram-se capacitados para agir em abrangência do todo - o nacional - ou ao menos de suas pátrias particulares, moldando segundo interesses próprios e nem sempre coincidentes, o formato assumido pelo Estado brasileiro, desde 1822.

\begin{abstract}
Supported by cartorial data - wills and "post mortem" inventories - this article intends to reconstruct the wealth, productive structures and labour relationships that distinguished proprietors established at Ouro Preto, São João Del Rey and Paracatu, as well as the Distrito Diamantino, from 1792 until 1831. Focusing on the material and social diversity of the Minas Gerais province, during a period characterized by an economical "accomodative evolution", I aim to shed some light on the different conditions and strategies available to those men who intended to obtain profit, without losing their social distinction, and by doing so, were able to act nationelly, or at least locally, shaping, according to their own interests, the Brazilian State.
\end{abstract}

\section{Palavras-chaves}

Estado / formas de governo, Minas Gerais, elites

\section{Keywords}

State / forms of government, Minas Gerais, elites 
1

Estudos oportunamente referidos no decorrer deste texto, grande parte dos quais tributários dos enfoques pioneiros de MARTINS, Borges. A economia escravista de Minas Gerais no século XIX. Belo Horizonte: Cedeplar/UFMG, nov/1980; SLENES, Robert W. 0 múltiplo de porcos e diamantes: a economia escravista de Minas Gerais no século $X I X$, in: Cadernos IFCH/Unicamp, Campinas, $n^{\circ} .17$, junho de 1985; LIBBY, Douglas Cole. Novas considerações sobre a protoindustrialização mineira nos séculos XVIII e XIX. Revista do Departamento de História, Belo Horizonnte: UFMG, n. 9, 1989, p.149160 e Transformação e trabalho em uma economia escravista - Minas Gerais no século XIX. São Paulo: Brasiliense, 1988; LENHARO, Alcir. As tropas da Moderação. 0 abastecimento da Corte na formação política do Brasil: 1808-1842). 2a. ed., Rio de Janeiro: Secretaria Municipal de Cultura, Turismo e Esportes/Departamento Geral de Documentação e Informação Cultural, Divisão de Editoração, 1993. 2

Sugestão esta precocemente apresentada em artigo de LINHARES, Maria Yedda Leite. 0 Brasil no Século XVIII e a Idade do Ouro: a Propósito da Problemática da Decadência. In: Seminário sobre a Cultura Mineira no Periodo Colonial. Belo Horizonte: Conselho Estadual de Cultura de Minas Gerais, 1979. p.166.

3

Acresce-se ainda as dificuldades de acesso e manejo da documentação pertinente, dispersa pelos arquivos municipais e regionais e, na maioria das vezes, em péssimo estado de conservação.
A constatação dos diferentes ritmos de sedimentação e desagregação da experiência colonial em cada porção da América portuguesa, tomados em suas coexistências, sincronias e diacronias, tem se tornado ponto de partida quase que incontornável para estudiosos interessados em compreender o processo que, iniciado com a crise do Antigo Regime português e a dissolução do Império luso-brasileiro, em 1822, cristalizará, nas primeiras décadas do XIX, as condições históricas para o surgimento do Estado e da Nação brasileiros.

Sob tal perspectiva, pesquisas monográficas, tematicamente recortadas e empiricamente embasadas, têm buscado decifrar o verdadeiro "enigma" inscrito nos fenômenos em causa, trazendo à tona as profundas singularidades que constituíram a porção americana da Monarquia portuguesa, as experiências históricas dos agentes aí radicados, suas concepções e percepções específicas do "viver em colônia", bem como as identidades coletivas e projetos políticos resultantes e produtores das realidades mais ponderáveis, presentes nos instantes de suas elaborações.

No bojo das análises que compartilham - intencionalmente ou não - do enfoque em causa, insere-se uma recente e promissora produção historiográfica sobre Minas Gerais. Assim, seja problematizando assuntos específicos à História econômica, seja enfrentando fenômenos até recentemente reconhecidos como intangiveis ou mesmo irrelevantes ao historiador, tais estudos contribuem, decisivamente, para o mapeamento da dinâmica e diversificada realidade material e social que compunha a região, entre meados do século XVIII e inícios do século XIX, com produção econômica voltada, sobretudo, para o mercado interno - mas, também articulada à praça mercantil carioca e de outras províncias -, ausência de grandes unidades monocultoras e uma população forra e escrava numerosa e em constante expansão1.

Em suma, uma realidade que não se enquadra nos modelos de economias de subsistência tradicionais e, tampouco, no das áreas agroexportadoras mas, nem por isso, reveladora de um genérico atraso ou estagnaação, justificando o esforço de abarcar suas "infinitas diversificações locais".2

De antemão, o tema impõe incontornáveis dilemas ao pesquisador, precipitando-se aqueles de ordem metodológica e operacional, fruto da própria dificuldade em se reconhecer a natureza e os limites das assimetrias em causa, identificar as variáveis relevantes na explicação de determinados fenômenos e processos, os parâmetros pertinentes de comparação e mensuração das mesmas, bem como as possibilidades de categorização de agentes tão diversificados nas suas inserções econômicas e relações de poder, nos seus sinais distintivos" e "formas de hegemonia", nos tipos de dependência que, inevitavelmente, multiplicam os sentidos de alteridade em relação aos quais assumem visibilidade e que, no limite, implodem com a possibilidade de generalizações acerca de categorias sociais pretensamente polarizadas em "elites" e "classes infimas". 3

Atentos a tais dificuldades e aos limites deste texto, as reflexões apresentadas abarcam recorte bem mais modesto. Sustentadas por fontes de natureza cartorial - testamentos e inventários post mortem -, buscase reconstituir a composição das fortunas, estrutura de posses e relacionamentos específicos com a propriedade, reveladoras de assimetrias 
4

JANCSÓ, István. Independência, Independências. In:________org.) Independência: História e Historiografia. São Paulo: Hucitec, 2005. p. 28. 5

KOSELLECK, Reinhart. "Espaço de Experiência" e "Horizonte de Expectativas": duas categorias históricas, in: Futuro Passado: contribuição à semântica dos tempos históricos. Rio de Janeiro: PUC-Rio/ Contraponto, 2006, p.305-327.

6

Tais reflexões se inserem no escopo da pesquisa de pós-doutoramento, que toma por eixo a articulação das expectativas econômicas e políticas advindas das diferentes inserções dos agentes estudados no cenário produtivo das Minas, com os projetos de Estado alternativos externados entre 1792 e 1831, bem como as identidades políticas coletivas que Ihes deram suporte. (SILVA, Ana Rosa Cloclet da. Identidades em construção. 0 processo de politização das identidades coletivas em Minas Gerais (1792-1831). Relatório (Pós-doutoramento)). São Paulo: Universidade de São Paulo/FFLCH, 2007.

7

LIBBY, Douglas Cole. Transformação e trabalho em uma economia escravista - Minas Gerais no século XIX. São Paulo: Brasiliense, 1988.

Tendência verificada desde finais do XVIII, conforme análise de Carla Almeida acerca do "Resumo Geral de roças, lavras e fazendas extraído da capitania de Minas Gerais o ano de 1766", elaborado pelo então Governador e Capitão-General Diogo Lobo da Silva. (ALMEIDA, Carla Maria C. de. Homens ricos, homens bons: produção e hierarquização social em Minas colonial (1750-1822). Tese (Doutorado em História). Rio de Janeiro: UFF, 2001. p.60-63).

9

À mesma época, as Comarcas de Vila Rica, Serro e Paracatu detinham, respectivamente, 14,6\%; 17,7\% e 5,3\% da população livre da provincia, contra $11,5 \% 13,5 \%$ e 2,2\%, respectivamente, do plantel de escravo. (MATOS, Raimundo José da Cunha. Corografia Histórica da Provincia de Minas Gerais (1837). Belo Horizonte: Imprensa Oficial, 1779, vol. II, p.43)

10

MAXWELL, K.. A devassa da Devassa. Inconfidência mineira, Brasil-Portugal, 1750-1808. Rio de Janeiro: Paz e Terra, 1977. p.300. entre os proprietários radicados nos Termos de Ouro Preto, São João Del Rey, Paracatu e do Distrito Diamantino, no periodo entre 1792 e 1831. De outro modo, busca-se inferir, a partir da diversidade material e social observada, estratégias de enriquecimento e distinção, comportamentos e hábitos, formas de expressão e legitimação de poderes, que, nestas diferentes partes das Minas de finais do XVIII e inícios do XIX, fizeram com que alguns indivíduos se afirmassem como "elites" em relação a outros que, a despeito de qualquer mobilidade social comportada pelo contexto da "acomodação evolutiva" da economia mineira oitocentista, foram (re) classificados em escalas hierárquicas subalternas.

Se do ponto de vista metodológico e conceitual o esforço de explicitação dos critérios que recomendam a utilização desta categoria de hierarquização das gentes - arremedo de um padrão societário que, na sua congênere européia, encontrava correspondência no estrato superior de nobreza $a^{4}$ - contribui para evitar tanto o anacronismo, quanto a indesejada indeterminação da análise, no concernente à dimensão analítica tem permitido desvendar elementos estruturantes do "espaço de experiências" 5 compartilhado por aqueles homens que, portadores de recursos materiais e simbólicos desiguais - ainda que indissociáveis da reiteração de posições de privilégio nas relações sociais - revelaram possibilidades concretas de atuação em abrangência do todo - o nacional -, ou ao menos de suas pátrias particulares, moldando segundo interesses próprios e nem sempre coincidentes o formato assumido pelo Estado brasileiro, desde 1822.6

\section{O UNIVERSO MATERIAL REVELADO PELAS FONTES}

\section{Ocupações e atividades produtivas dos inventariados}

A despeito das especificidades comportadas por cada região analisada, os dados extraídos dos inventários pesquisados - um total de 222, selecionados de acordo com 4 sub-períodos abarcados pela cronologia geral (1792-1794; 1808-1810; 1821-1822; 1829-1831) - confirmam uma característica estrutural do período estudado: qual seja, a consolidação da economia mercantil de subsistência, iniciada no pós-auge minerador e dinamizada a partir de 1810, cujos efeitos fizeram-se sentir não apenas em termos demográficos, mas na diversificação econômica verificada entre as regiões e dentro das próprias unidades de produção. ${ }^{7}$

$\mathrm{Na}$ esteira de recentes estudos, corroboram assim tanto o generalizado predomínio numérico das atividades agropecuaristas sobre as lavras ${ }^{8}$, quanto a maior importância assumida pela Comarca do Rio das Mortes, a qual, englobando o Termo de São João Del Rei, convertera-se no principal núcleo produtor e intermediador do comércio com a praça carioca. Tal importância se reflete nos dados de demografia, os quais indicam que, em 1821, a região concentrava cerca de $38,7 \%$ da população livre de toda a província e nada menos que 47\% do plantel escravo mineiro ${ }^{9}$, revelando-se esta uma tendência desde finais do XVIIII0.

Infelizmente, não dispomos de estatísticas confiáveis que nos permitam acompanhar as mesmas informações para os Termos analisados e, tampouco, para as Freguesias por eles abarcadas. Fiando-nos 
MATOS, Raimundo José da Cunha. Corografia Histórica da Província de Minas Gerais (1837). Belo Horizonte: Imprensa Oficial, 1779, vol. II. p.44-60. 12

PAIVA, Eduardo França. Escravos e Libertos nas Minas Gerais do século XVIII. Estratégias de resistência através dos testamento. 2a. Ed. São Paulo: Annablume, 1995. p.73.
13

Analisando dados relativos ao triênio de 1765-68, quando a arrecadação esteve a cargo da Fazenda Real, Carla Almeida conclui que, embora até esta data fosse a Comarca de Vila Rica que mais gerava recursos (34,2\% do total da arrecadação), tendo ainda o maior valor médio por contribuinte, a localidade que apresentava a maior média de pagamento (por volta de $64,1 \%$ a mais de dizimos do que a média da Capitania) era a Freguesia do Caminho Novo, situada justamente na rota do circuito mercantil Rio-Minas. Tal tendência é corroborada pelo acompanhamento da arrecadação dos dízimos a partir dos dados levantados por Carrara o qual, baseando-se na documentação da Casa dos Contos de Ouro Preto, detectou que no periodo de 1750 a 1807 somente as freguesias da Comarca do Rio das Mortes apresentaram aumento do rendimento dos dizimos, sobretudo as situadas mais ao sul, detentoras de amplas possibilidades de expansão e adequação para o desenvolvimento das atividades agropastoris, como eram os casos de Baependi, Campanha e Aiuruoca. (ALMEIDA, Carla Maria C. de. Homens ricos, homens bons: produção e hierarquização social em Minas colonial (1750-1822). Tese (Doutorado em História). Rio de Janeiro: UFF, 2001. p.67; CARRARA, Ângelo Alves. Agricultura e pecuária na capitania de Minas Gerais (1674-1807). Tese, (Doutorado). Universidade Federal do Rio de Janeiro, Rio de Janeiro, 1997. p.191-192.

14

Mesmo no Distrito, onde a atividade econômica predominante sempre esteve fincada na extração dos diamantes e do ouro - havendo ainda uma esterilidade caracteristica dos solos que obstava em grande medida a agricultura nestas áreas, deslocando-a para as terras férteis situadas a leste da região -, verifica-se o predomínio destas atividades (59\%), relegando o peso da mineração para os 41\% restantes. (PAIVA, Clotilde. População e Economia nas Minas Gerais do Século XIX. Tese (Doutorado). São Paulo: Universidade de São Paulo, Depto de História, 1996. p.116.) no resumo demográfico utilizado por Cunha Matos ${ }^{11}$ e sistematizado por França Paiva12, para o mesmo ano, constatamos que os Termos de Vila Rica, São João Del Rei, Vila do Príncipe e Paracatu apresentavam, respectivamente, os seguintes percentuais da população livre e escrava da provincia:

\begin{tabular}{|c|c|c|c|c|}
\hline Termos & Livre & Escrava & Total & \% Escrava/ Total \\
\hline Ouro Preto & $3,5 \%$ & $3,4 \%$ & $3,5 \%$ & $32 \%$ \\
\hline São João & $5,8 \%$ & $6,3 \%$ & $6,0 \%$ & $35 \%$ \\
\hline V. Príncipe & $11,6 \%$ & $9,8 \%$ & $11,0 \%$ & $29 \%$ \\
\hline Paracatu & $2,7 \%$ & $1,4 \%$ & $2,2 \%$ & $27 \%$ \\
\hline
\end{tabular}

Com exceção de São João, todas as demais localidades situavamse abaixo da participação percentual dos escravos sobre a população total da província que, segundo Maxwell, era de 33\%. Apesar disso, o Termo sanjoanense concentrava apenas 6,3\% do plantel mineiro, sendo suplantado por 5 outras localidades, incluindo a Vila do Príncipe, perfil que talvez se explique em função da divisão administrativa selecionada, a qual exclui alguns dos principais núcleos produtores da Comarca - caso das propriedades situadas nos Termos de Barbacena, São José, Queluz e Baependi -, mais diretamente articulados ao mercado carioca e dependentes de grandes plantéis.

Se os insuficientes dados demográficos sobre cada região não nos permitem ilações, a documentação inventarial pesquisada parece corroborar tendências mais gerais, observadas em nível das Comarcas. Por um lado, com inegáveis impactos sobre a capacidade de geração de recursos para a Coroa ${ }^{13}$, a distribuição da riqueza por região relaciona-se às transformações processadas em nivel da estrutura produtiva de cada uma delas.

Num esforço de esclarecimento acerca deste último aspecto, observase a predominância das atividades agropastoris - inclusive nos antigos núcleos mineradores ${ }^{14}$-, cuja difusão se explica em virtude da maior facilidade do acesso às "terras de cultura" pelos pequenos proprietários - vis-á-vis as tão disputadas datas -, demandando ainda um menor número de cativos, contrariamente à mineração. A tabela abaixo, extraída da documentação pesquisada, permite confirmar alguns destes argumentos:

Distribuição da mão-de-obra escrava e monte-mor médio pelas unidades produtivas

\begin{tabular}{|c|c|c|c|c|c|c|c|c|}
\hline \multirow[t]{2}{*}{ Termos } & \multicolumn{2}{|c|}{$\begin{array}{l}\mathrm{N}^{\circ} \text {. de } \\
\text { Escravos na } \\
\text { Mineração }\end{array}$} & \multicolumn{2}{|c|}{$\begin{array}{l}\mathrm{N}^{\circ} \text {. de } \\
\text { Escravos na } \\
\text { Agropecuária }\end{array}$} & \multicolumn{2}{|c|}{$\begin{array}{l}\text { Monte-mor médio } \\
\text { na mineração }\end{array}$} & \multicolumn{2}{|c|}{$\begin{array}{l}\text { Monte-mor médio } \\
\text { na agropecuária }\end{array}$} \\
\hline & Total & Médio & Total & Médio & Mil-Réis & Libras & Mil-réis & Libras \\
\hline $\begin{array}{l}\text { Ouro } \\
\text { Preto }\end{array}$ & 20 & 6 & 51 & 4 & $1: 941 \$ 192$ & 594,0 & $1: 535 \$ 960$ & 470,0 \\
\hline São João & 43 & 14 & 171 & 13 & $2: 830 \$ 088$ & 866,0 & $5: 480 \$ 436$ & 1677,0 \\
\hline Distrito & 36 & 6 & 140 & 8 & $2: 539 \$ 236$ & 777,0 & $2: 392 \$ 176$ & 732,0 \\
\hline Paracatu & & & 149 & 3 & & & $900 \$ 334$ & 275,5 \\
\hline
\end{tabular}


15

É o que atesta o caso de Bernardo Antônio da Roxa, solteiro, natural de São João Del Rei, residente no arraial do Tejuco, onde ocupava o cargo de feitor da Régia extração diamantina. Em seu inventário, constavam créditos referentes à posse de bilhetes correntes da real extração, no valor de $311 \$ 287$ réis; a quantia de $55 \$ 987$ réis, relativa ao seu ordenado do primeiro semestre de 1809, e "jornais dos seus escravos vencidos na segundo semestre do mesmo ano", que ainda se achavam na contadoria", no valor de $124 \$ 687$ réis. Sobre o tema, ver: FURTADO, Júnia F.. O Livro de Capa Verde. 0 Regimento diamantino de 1771 e a vida no Distrito Diamantino no período da Real Extração. São Paulo: Annablume, 1996. p.48-49.
Uma primeira observação a partir da tabela acima se relaciona à capacidade da agropecuária absorver mais amplamente a mão-de-obra escrava, relativamente à mineração, em todas as localidades estudadas. Se cruzarmos estes dados com o número total de escravos arrolados nos inventários pesquisados para cada região, constataremos que, no Termo de Ouro Preto, a agropecuária utilizou-se de 29,8\% desta mão-de-obra; em São João Del Rei, de 57,9\%; em Paracatu, de 52,4\% e, no Distrito Diamantino, este percentual chegou a 62,2\%. Este último caso merece ressalva, uma vez que a mineração, assim como o número médio de escravos que empregava, certamente teve maior peso em toda Comarca do Serro, que o sugerido pelos dados acima. Isto porque, apresentando o mais elevado percentual de proprietários de porte médio - em nossa amostragem, representados pelos plantéis de 6 a 10 cativos -, as condições especificas da extração dos diamantes permitia aos proprietários comprarem escravos para serem alugados à Real Extração, detentora do controle oficial da atividade, representando esta uma difundida alternativa econômica para a crise, que separava o uso e a propriedade do escravo..$^{15}$

Muito embora a agropecuária tenha utilizado maior número absoluto de escravos, os dados acima indicam que a mineração precisou manter maiores plantéis, variando o número médio de escravos empregados nesta atividade entre 6 e 14 escravos, ao passo que na primeira esta cifra não ultrapassou 13 cativos, justamente na Comarca que revelava maior tendência à mercantilização da produção. É ainda em São João que o monte-mor médio dos proprietários englobados no setor agropecuário revelou maior disparidade em relação ao monte-mor médio relativo à mineração, sendo 48,36\% superior, ao passo que nas demais regiões - exceção feita a Paracatu, onde não foi identificado nenhum inventário com atividade mineratória -, parece ter havido uma distribuição mais eqüitativa da riqueza entre as duas atividades.

Além de não atenuar a hierarquização extremamente polarizada entre ricos e pobres - verificada tanto em nível das Comarcas, quanto dos Termos que abarcavam -, a difusão espacial da agropecuária não mascara a decorrência da maior lucratividade do capital mercantil sobre o produtivo, qual seja, as maiores possibilidades de enriquecimento abertas aos proprietários da região do Rio das Mortes - dado que a dinamização do comércio aí marcara mais fortemente a fase da "acomodação evolutiva" -, refletida no cálculo do monte-mor médio por localidade:

Monte-mor médio por localidade, em libras esterlinas

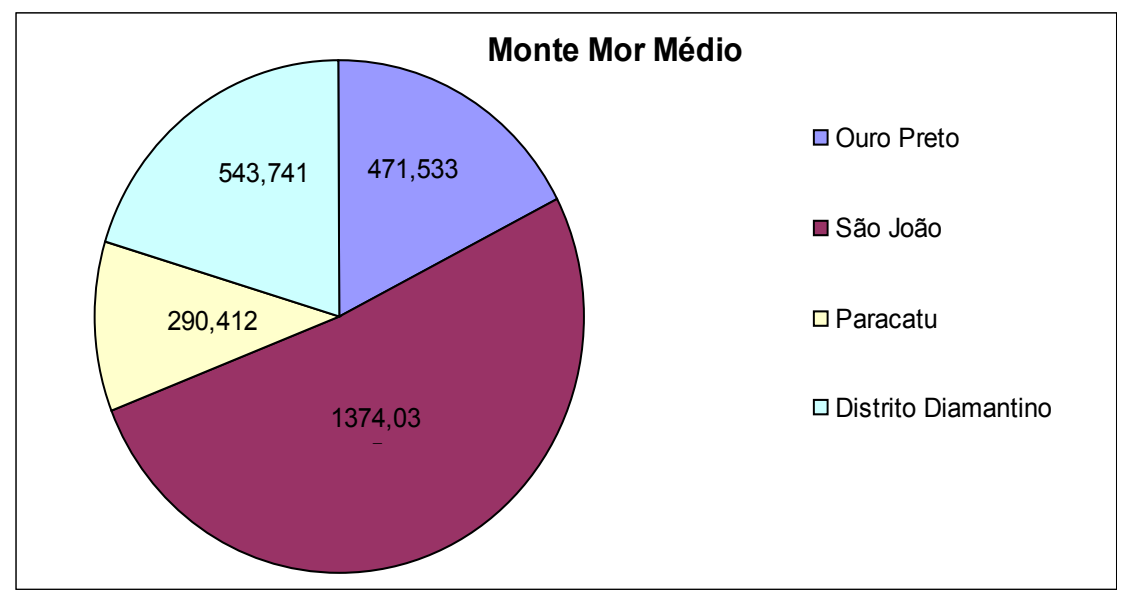


"Mapas do Barão de Eschwege", para o período de 1818-1819, in: MATOS, Raimundo José da Cunha. Corografia Histórica da Província de Minas Gerais (1837). Belo Horizonte: Imprensa Oficial, 1779, vol. II, p.322-324. Segundo esta tendência, das 14 unidades produtivas que mencionam os produtos cultivados para o Termo de Ouro Preto e a área do Distrito Diamantino, 7 revelam explicitamente o cultivo de mandioca e a presença de moinho e forno, indicando a produção de farinha; 3 produzem milho, também com presença de moinho, 2 produzem ambos os produtos e 2 apenas se referem a "plantações" com presença de "moinhos", o que sugere a inclusão num dos itens anteriores. No Termo de Paracatu, a produção de viveres - feijão, arroz, milho, mandioca - está presente em 8 das 16 unidades agrárias em que foi possivel identificar 0 produto, ao passo que, em São João Del Rei, 5 dos 15 estabelecimentos que desenvolvem a agropecuária cultivam 1 ou mais destes gêneros. 17

Esta regionalização mais ampla é adotada por PAIVA, Clotilde. População e Economia nas Minas Gerais do Século XIX. Tese (Doutorado). São Paulo: Universidade de São Paulo, Depto de História, 1996. 18

Na região do Distrito, a unidade produtiva mais diversificada por nós encontrada foi a de Rita Quitéria, casada com o Alferes Bento Dias Chaves, proprietária de "uma morada de casas de Sobrado na Rua do Senhor do Bom" e de uma fazenda, com "dois monjolos e engenho de pilões, uma roda de mandioca, um Alambique de cobre", "um torno de ferreiro já usado", "dois paióis que servem para colher malho", "seis cangas com três tiradeiras" e dois carros com seu uso". Constavam, ainda, entre seus bens: "dois teares de tecer Festoins e Gongos com todos os seus aparelhos", mais "um tear de tecer várias qualidades de fitas com todos os seus pertences e aparelhos". Estes últimos instrumentos, indicando presença de vinculos mercantis não apenas intra-regionais, mas com outras províncias - dado serem os tecidos de algodão um dos principais produtos de exportação de Minas para 0 Rio de Janeiro, compondo cerca de 96\% dos item com tal destino. (Inventário post mortem de Rita Quitéria de São José Fernandes de Oliveira Lucena. (BAT, maço 63, ano 1808)).

19

É assim que, no Termo de Ouro Preto, das 7 unidades agropecuárias em que foi possivel identificar o produto, 5 encaixam-se neste modelo, sendo que 2 associam o cultivo e fabricação de farinhas de mandioca e milho com mineração e alguma indústria doméstica, 2 apenas consorciam os gêneros em causa com atividades de transformação (indústria rural) e 1 revela presença de engenho, com produção de derivados da cana. No Distrito, por sua vez, 4 unidades produtivas inserem-se neste perfil de fazenda mista, das quais 3 revelam presença de indústria doméstica - 3 teares e rodas de fiar; 3 instrumentos de ferreiro, 1 marcenaria e 2 consorciamento com a plantação e produção de derivados de cana.

20

É o que revelam os Inventários post mortem de Alexandre da Cunha Matos (CPOP, Cód. 56, auto 632, ano de 1830) e Manoel da Rocha Pereira. (CPOP, cód. 42, auto 475, ano de 1831).

21

SAINT-HILAIRE, Auguste de. Viagem pelo distrito dos diamantes e litoral do Brasil. Belo Horizonte/
As assimetrias regionais se expressam ainda em nivel da estrutura ocupacional dos estabelecimentos produtivos considerados. Perquirindo esta variável, verificou-se o difundido cultivo de alimentos voltados para o mercado intra-regional, sobressaindo aqueles gêneros que, de acordo com as informações coligidas por Eschwege, incluem-se justamente entre os 6 não exportados para o Rio de Janeiro: o milho, a farinha de mandioca e o feijão ${ }^{16}$.

Além disso, a produção de gêneros de subsistência vinha, na maioria das vezes, conjugada à daqueles destinados ao comércio, elaborados ou não por atividades de transformação e artesanais. Este revelou-se um perfil generalizado das unidades produtivas mineiras, sendo uma das formas consorciadas de produção mais comuns aquela estabelecida entre a agricultura e o processamento dos gêneros acima mencionados, a pecuária - variando a composição do rebanho -, as atividades agroaçucareiras e a indústria doméstica, especialmente a fiação e tecelagem, funilaria, carpintaria e marcenaria. Em alguns casos, conta-se ainda com a presença da mineração.

Esta constatação sugere a difusão do modelo de "fazenda mista", presente em todas as regiões analisadas, mas expressivamente mais sofisticado no concernente às técnicas e diversificação dos produtos na região Sudeste - sobressaindo as exportações de queijos, toucinho bovino, tabaco, suinos e tecidos para o Rio de Janeiro, sendo ainda importante entreposto comercial de víveres, provindos de Minas Novas e da região intermediária de Pitangui-Tamanduá - e na Mineradora Central Oeste17 - onde o Termo de Ouro Preto e a área do Distrito contavam com uma pauta de exportações variada, seja de viveres para as áreas de mineração, seja de matérias-primas para serem transformadas ou revendidas, para outras regiões - caso do algodão 18 - e artefatos de ferro para lavoura e mineração ${ }^{19}$. Em alguns casos, a interação entre estas atividades desenvolvidas no interior de uma mesma unidade produtiva implicava, ainda, certa auto-suficiência do proprietário no ramo em questão. ${ }^{20}$

Em São João Del Rei, das 9 unidades produtivas que se encaixam no modelo de "fazenda mista", 5 revelam como atividade associada à agropecuária a fiação e tecelagem. Diversos viajantes notaram a importância do cultivo, fabricação e comércio dos tecidos de algodão no Rio das Mortes, destacando-se, nesta atividade, os comerciantes da Vila sanjoanense que, segundo Saint-Hilaire, compravam o algodão das outras partes da Comarca, descaroçavam-no e prensavam-no em sacos de couro (os "alforjes", freqüentemente descritos entre os bens dos inventariados) ${ }^{21}$. A manufatura têxtil tinha caráter doméstico, utilizando-se predominantemente da mão-de-obra feminina, livre e escrava. ${ }^{22}$.

Além dos tecidos de algodão, chamam a atenção 3 outros produtos amplamente exportados para o Rio de Janeiro: porcos (89\% das exportações mineiras destinadas àquela província), dos quais se extraía 0 toucinho (outra especialidade minera, da qual 97\% tinha o mesmo destino); e gado vacum (78\% também exportados para o Rio). ${ }^{23}$

Este último gênero provinha, sobretudo, da região de Paracatu, a qual comercializava apenas um artigo de considerável importância regional, o couro, embora a produção regional de alimentos para praças mais distantes também ocorresse. Neste sentido, São João convertia-se num intermediário para engorda do gado e sua comercialização com o Rio de Janeiro, implicando que os comerciantes do noroeste mineiro 
São Paulo: Itatiaia/Edusp, 1974. p. 47 (seus relatos se referem ao período de 1817-1822).

22

Conforme estudo de Ângela Magalhães baseado em listas nominativas dos municípios de São João Del Rei e Campanha, segundo o qual, entre 183132 , cerca de $39,1 \%$ das mulheres livres e $64 \%$ das escravas, dedicavam-se a tal atividade (MARTINS, Ângela Magalhães. Século XIX: estrutura ocupacional de São João Del Rei e Campanha. In: $V$ Seminário sobre Economia Mineira. Diamantina: CEDEPLAR, 1990). Este perfil é confirmado por nossa amostragem, a qual traz como casos paradigmáticos os Inventários post mortem de Escolástica Maria do Bom Sucesso (MRSJDR, cx 34, ano 1822); Capitão José Francisco da Costa e Antônia Maria de Jesus (MRSJDR, cx 128, ano de 1831); Leonor Maria da Conceição (MRSJDR, cx 466, ano de 1822) Antônio José da Silva e Ana Josefa Cândida (MRSJDR, cx 243, A0 DE 1831); Ana Ignácia da Costa (MRSJDR, cx. 66, ano de 1808).

23

Inventário post mortem do Tenente Manoel Joaquim de Andrade e Lauriana de Souza Monteiro. (MRSJDR, cx. 565, ano 1822).

24

Segundo Paiva, não havia nem mesmo sinais de que o beneficiamento do couro e a produção de gêneros da terra, comercializados com a Bahia, fosse lucrativo para os comerciantes locais, "que vendiam seus produtos por preços muito baixos". (PAIVA,

Clotilde A. População e Economia nas Minas Gerais do Século XIX. Tese (Doutorado). São Paulo: Universidade de São Paulo, Depto de História, 1996. p.119).

25

Assim, das 28 fazendas descritas nos inventários, apenas 5 apresentam dois ou mais destes equipamentos, a maioria mencionando apenas a pecuária ou sua associação com a agricultura de víveres não exportáveis para o Rio de Janeiro: feijão, milho e mandioca.

26

Marcelo Godoy destaca esta habitual consorciação da mineração aurífera com a atividade agroaçucareira, em princípio mais comum nas regiões ao norte da capitania - com destaque para Minas Novas -, mas presente mesmo na área mineradora central, tendência que adentrara o século XIX quando, apesar da diminuição da mineração, a estrutura produtiva das fazendas mineiras permaneceu diversificada, associando agricultura, pecuária e indústria rural. (GODOY, Marcelo Magalhães, "No pais das

Minas de ouro a paisagem vertia engenhos de cana e casas de negócio. Um estudo das atividades agroaçucareiras tradicionais mineiras entre o Setecentos e o Novecentos e do complexo mercantil da provincia de Minas Gerais". Tese (Doutorado). São Paulo: FFLCH/Universidade de São Paulo, 2004. p.58-63.). 27

Inventário post mortem de Baltazar Estácio de Oliveira (APMOG, caixa/ano 1822).

28

ANDRADE, Francisco Eduardo. A enxada complexa: roceiros e fazendeiros em Minas Gerais na primeira metade do século XIX. Dissertação (Mestrado). Universidade Federal Minas Gerais, Belo Horizonte, 1994.

29

Segundo Graça Filho, "sob o risco da divisão das fazendas, com a subseqüente diminuição das pastagens em comum, os mineiros se obrigaram à negociação cotidiana de seus interesses com a parente- ficassem subordinados àqueles da Vila sanjoanense, onde os lucros se acumulavam. ${ }^{24}$.

É ainda nesta região que as atividades artesanais desenvolvidas no interior das unidades produtivas se revelam menos expressivas, sendo geralmente representadas pelos "fornos de cobre", utilizados na confecção das farinhas de mandioca e milho, e rodas de "ralar mandioca" e "fiar algodão"25. Mais comum no Termo paracatuense revelou-se a consorciação da pecuária com a produção da cana e seus derivados 26 . Aliás, difundidos por todas as regiões consideradas, os dados de nossa amostragem indicam que os engenhos de açúcar e aguardente eram mais comuns em consorciamento com a pecuária bovina, principal atividade das fazendas do noroeste mineiro. ${ }^{27}$

É importante salientar que, embora a diversificação das atividades econômicas tenha se convertido no modelo predominante das fazendas, tal perfil preserva-se também no interior daquelas unidades produtivas menores, descritas nas fontes como "sítios", "chácaras", "porções de terras", "terras de cultura" ou "terras de criar e plantar"28. Nestes casos, era comum ainda o proprietário mencionar mais de uma "porção" ou "parcela" de terras ou instalações em distintas fazendas e regiões, representando, para uns, estratégia de diversificação do investimento - e, conseqüentemente, diminuição dos riscos - além de evitar a fragmentação das terras ${ }^{29}$; para os menos abastados, a chance de incluirem-se no rol dos proprietários e donos de escravos, sem o despendimento de grandes montantes de capital. 30

Deve-se ainda mencionar a situação de imóveis urbanos, localizados na periferia das Vilas e que se utilizavam de seus quintais para desenvolver atividades tão diversificadas, preservando uma característica comum ao Setecentos mineiro, ou seja, o fato de que "servir de moradia e de unidade produtiva, em toda a sua extensão física, parecem ter sido as funções mais recorrentes da casa. Morar fora dos limites urbanos, em fazendas, sítios e chácaras, significou, constantemente, envolvimento dos proprietários com plantações, engenhos e criação de animais".31

0 gráfico abaixo sistematiza o perfil das unidades produtivas para cada região selecionada, conforme os modelos de fazenda mista; fazenda monocultora ou simplesmente agropecuarista (sem transformação do produto); sítios, chácaras e terras de cultura não descritas como fazendas, mas situadas fora das cidades, e os casos de culturas e criações em quintais urbanos.

\section{Estrutura Ocupacional das Unidades Produtivas}

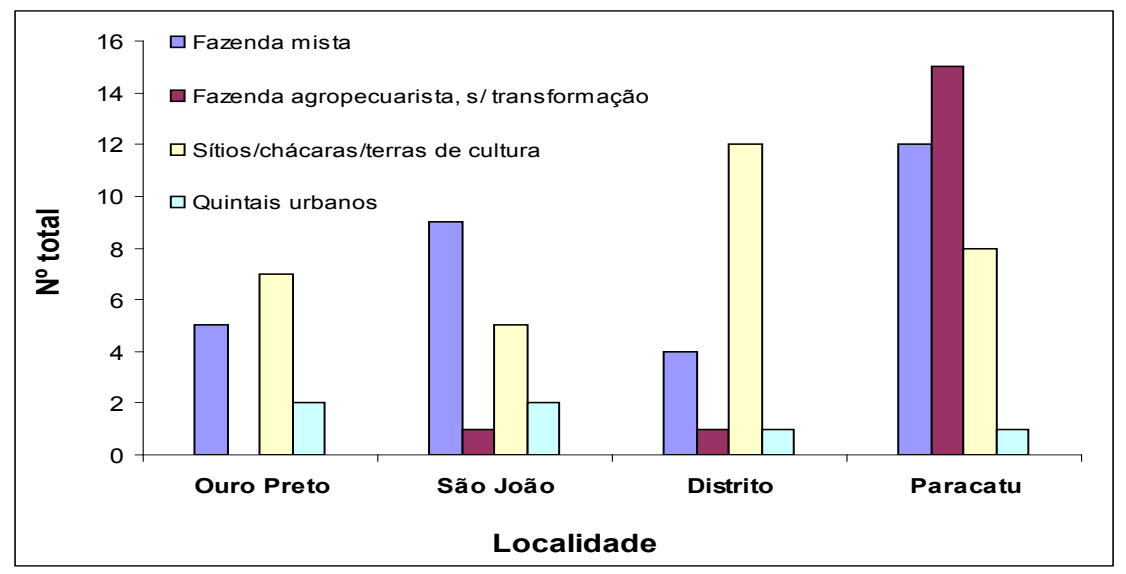


la", preocupação que, muito provavelmente, implicara na natureza dos dotes concedidos, que nunca incluiam terras. (GRAÇA FILHO, Afonso Alencastro. A Princesa do Oeste e o Mito da Decadência de Minas Gerais. São João Del Rei (1831-1888). São Paulo: Annablume, 2002. p.120-121).

30

Ilustrativo da primeira situação é o Inventário post mortem de Anselmo Lopes Vilas Boas (BAT, Maço 2, $1^{\circ}$. Of., 1831).

31

PAIVA, Eduardo França. Escravos e Libertos nas

Minas Gerais do século XVIII. Estratégias de resistência através dos testamento. 2a. Ed. São Paulo:

Annablume, 1995. p.168.

32

Este mesmo perfil é identificado por Paiva, para toda a região do Triângulo mineiro, por volta de 1831. ( PAIVA, Clotilde A. População e Economia nas Minas Gerais do Século XIX. Tese (Doutorado). São Paulo: Universidade de São Paulo, Depto de História, 1996. p.140)

33

Segundo Cunha Matos, Minas Gerais produzira tecidos de linho e algodão de excelente qualidade, contando ainda com fábricas de tecidos de lã. Estes últimos, porém, classifica como "sofrivelmente bons". (MATOS, Raimundo José da Cunha. Corografia Histórica da Província de Minas Gerais (1837). Belo Horizonte: Imprensa Oficial, 1779, vol. II. p.101).

34

Tal fato se explica, em grande medida, pelas condições geográficas da região, desprovida de grandes extensões de campos para pastagem, inviabilizando a pecuária bovina nas mesmas proporções do Termo sanjoanense. Revelava-se, assim, mais apta para a produção mercantil de suínos, associada ao cultivo do milho, outro produto que ai encontrava condições propícias de produção.

35

Segundo Carla Almeida, já em 1762, os homens de negócio da Vila de Ouro Preto ponderavam aos camaristas as vantagens do gado muar, pois: "enquanto o cavalo que se ocupa em conduta dos caminhos de Minas o mais que pode durar são sete anos (...) uma besta muar não deixa de exceder a doze. Um cavalo carrega menos peso, viaja menos caminho e nem todos pastam soltos, sendo uma besta muar em tudo diferente(...)". (Apud, ALMEIDA, Carla Maria C. de. Homens ricos, homens bons: produção e hierarquização social em Minas colonial (1750-1822). Tese (Doutorado em História). Rio de Janeiro: Universidade Federal Fluminense, 2001. p.119).

36

É o caso do inventariado José da Costa de Carvalho, cuja ocupação identifica como "viandante", proprietário de 88 cabeças de gado eqüino. (Inventário post mortem de José da Costa Carvalho-CPOP, cód. 85, auto $1037,1^{\circ}$. Of., ano de 1793).
Nota-se que as fazendas onde não são mencionadas atividades de transformação do produto ou qualquer outra forma de indústria doméstica predominam no Termo paracatuense, representando as grandes extensões de terra onde o gado bovino e eqüino, em especial, era criado de forma extensiva 32 . No caso do Distrito Diamantino, esta agropecuária era geralmente desenvolvida no interior das unidades produtivas menores, classificadas como "sítios", sendo freqüente, além da pecuária bovina - difundida por todo território das Minas -, a criação de animais utilizados no transporte de cargas (as mulas) e humano (os cavalos), bem como de suínos e ovinos, estes últimos usados para extração da lã33 .

Perfil semelhante se repete para o caso de Ouro Preto, com a diferença de que ai a dimensão dos rebanhos se mostra sensivelmente menor que nas demais regiões, predominando o gado eqüino, seguido pelo suíno e muar ${ }^{34}$. Este último foi predominantemente empregado no transporte de cargas, sendo em alguns casos também usado como tração animal. Sua maior proporção relativamente ao rebanho muar de São João se deve, em grande medida, à maior distância em relação à praça mercantil carioca e às condições geográficas inóspitas, dificultando o transporte das cargas por gado cavalar ${ }^{35}$. Apesar disso, este continuou sendo criado em grandes proporções, não apenas para ser comercializado - o que justifica os grandes rebanhos presentes em nossa amostragem ${ }^{36}$ - mas como principal meio de transporte para os moradores locais, preservando-se, desse modo, como um traço "arcaizante" no comportamento dos ouropretanos, garantia de "nobreza" e "bom tratamento".

0 gráfico abaixo ilustra estas distintas composições do rebanho nas regiões estudadas:

Participação \% dos rebanhos, por localidade

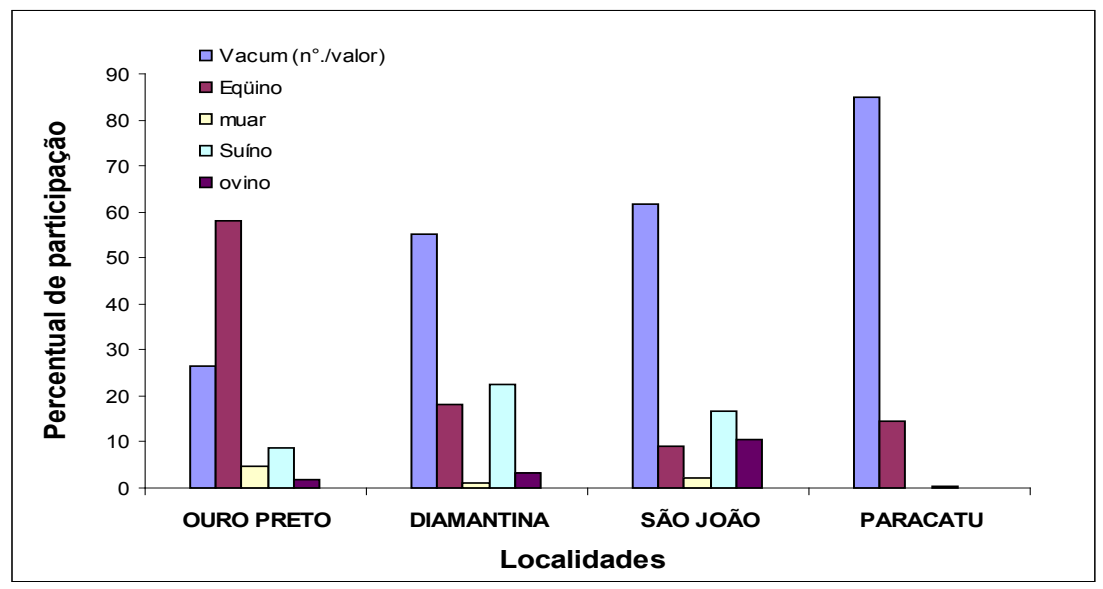

A partir deste breve e parcial mapeamento das atividades produtivas predominantes por região estudada, verifica-se que, se de fato as especificidades locais orientaram as possibilidades de investimento, para todas elas delineia-se a tendência da conjuntura: a lógica da diversificação das atividades no interior das próprias unidades produtivas e os marcantes vinculos com o mercado, estando as possibilidades de inversão lucrativa do capital na direta proporção destas duas variáveis, assim como as relações com a mão-de-obra escrava. Fixando esta última variável, chegamos ao seguinte perfil da estrutura de posses de cativos, por localidade: 
37

Inventário de Ignácia da Costa (MRSJDR, cx. 66, ano de 1808).

38

Inventário post mortem do Capitão Gonçalves Barbosa (MRSJ, cx. 70, 1792).

39

Segundo estudo de Paiva, a menos densamente povoada de Minas. (PAIVA, Clotilde A. População e Economia nas Minas Gerais do Século XIX. Tese (Doutorado). São Paulo: Universidade de São Paulo, Depto de História, 1996. p.144).

40

Embora relativamente inferior ao caso paracatuense, o número de proprietários sem escravos também é elevado em São João. Aqui, também, é provável que tal perfil esteja associado às maiores chances abertas pela economia mercantil de subsistência, dada a facilidade de aquisição das "terras de cultura", conforme veremos adiante.

41

Analisando a atividade fiscal dos registros mineiros no setecentos, Cláudia Chaves destaca o padrão então predominante: grande número de pequenos comerciantes eventuais, não especializados, com exceção dos grandes fazendeiros, ligados à pecuária, únicos para os quais se pode falar em monopólio e estabilidade, não havendo para eles incerteza do lucro. (CHAVES, Cláudia Maria das Graças. Perfeitos negociantes: mercadores das Minas setecentistas. Dissertação (Mestrado). Universidade Federal de Minas Gerais, Belo Horizonte, 1995).

42

Respectivamente, os Inventários post mortem de Baltazar Estácio de Oliveira (APMOG, caixa/ano 1822); Margarida da Silva de Jesus (APMOG, cx/ano 1822); e José da Costa Coimbra (APMOG, cx/ano de 1809)).

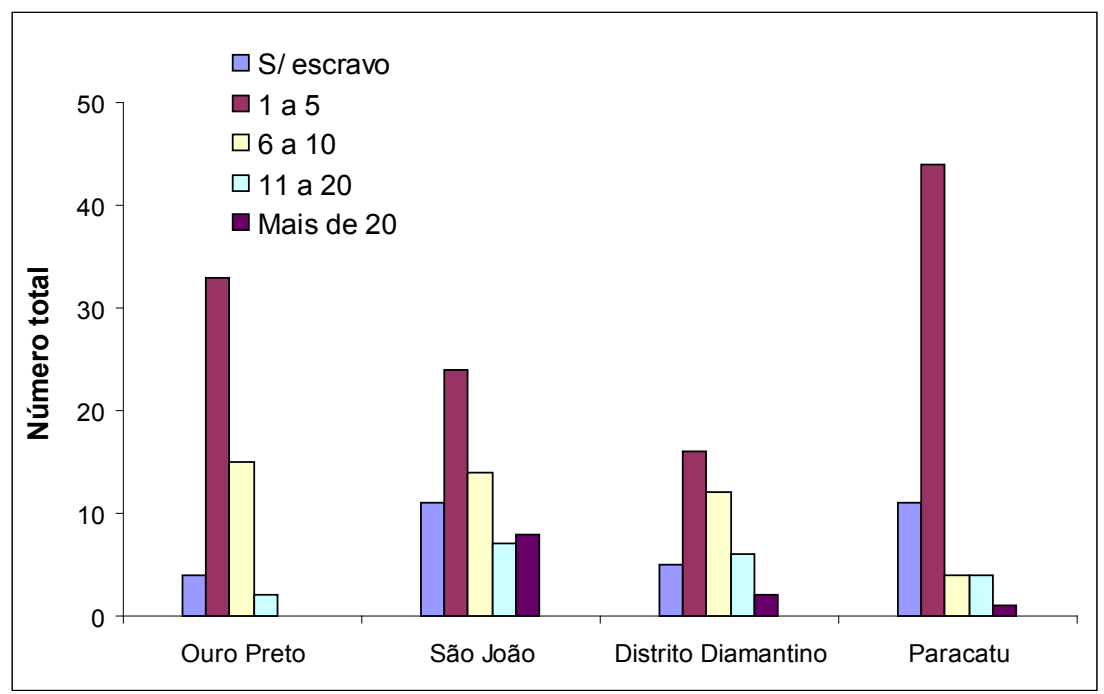

Pelo gráfico acima, observamos que predominam os pequenos plantéis (1 a 5) em todas as regiões, havendo um maior equilibrio entre pequenos e médios ( 6 a 10 escravos) na região do Distrito - pelo fato já referido de, nesta região, a posse estar dissociada da propriedade dos escravos -, situação que se assemelha à de Ouro Preto onde, porém, é maior a disparidade entre o número de pequenos e médios proprietários, provavelmente em função de uma vida urbana mais dinâmica, demandando menores plantéis.

Em São João sobressai o número dos grandes e médios escravistas, inseridos, respectivamente, nas faixas acima de 20 e entre $11 \mathrm{e}$ 20 cativos, concentrados justamente nas unidades com maior tendência à mercantilização da produção - em especial aquelas que consorciavam mais de 2 atividades $^{37}$ - ou nos grandes estabelecimentos comerciais urbanos, geralmente monopolizados por portugueses 38 .

Paracatu, por sua vez, é onde a posse de escravos aparenta estar mais pulverizada, havendo ainda o maior número de não proprietários de escravos. Este último aspecto pode ser atribuído, em parte, à própria extensão de terras desabitadas na região ${ }^{39}$, implicando que a população livre pudesse ocupar espaços de "fronteira aberta", desenvolvendo nestes atividades ligadas ao auto-consumo, não dependentes do braço escravo ${ }^{40}$. Contudo, mesmo aqui, eram as fazendas de criação extensiva, articuladas ao ramo mais estável, monopolizado e lucrativo do comércio de longa distância ${ }^{41}$, onde a pecuária bovina era geralmente consorciada com os engenhos de aguardente e derivados, que mais absorviam mão-de-obra escrava, conforme atestado pelos 3 maiores plantéis de nossa amostragem ${ }^{42}$.

À assimétrica distribuição regional e produtiva da mão-de-obra escrava pelas regiões mineiras consideradas, sobrepunha-se, ainda, uma estrutura de posse visivelmente concentrada deste ativo. A tabela abaixo apresenta a proporção entre o número de proprietários e a posse de plantéis inseridos nas faixas média superior (11 a 20) e alta (acima de 20) de cativos: 
Concentração da posse de escravos por localidade

\begin{tabular}{|c|c|c|c|}
\hline LOCALIDADES & $\begin{array}{c}\text { No. Total do } \\
\text { Plantel }\end{array}$ & $\begin{array}{c}\text { \% proprietários } \\
\text { (médias e grandes posses) }\end{array}$ & $\begin{array}{c}\text { \% da escravaria } \\
\text { concentrada }\end{array}$ \\
\hline Ouro Preto & 248 & $3,7 \%$ & $10,4 \%$ \\
\hline São João & 592 & $27 \%$ & $70 \%$ \\
\hline Distrito & 284 & $20 \%$ & $49 \%$ \\
\hline Paracatu & 225 & $7,8 \%$ & $36,8 \%$ \\
\hline
\end{tabular}

Os dados acima indicam que, embora houvesse uma desconcentração da posse de cativos na base (um grande número de pequenos proprietários com pequenas posses), há uma tendência à concentração no topo (pequeno número de proprietários com grandes posses), o que nos parece mais acentuado no caso de São João Del Rei.

Se levarmos em conta que na sociedade da época escravo era sinal de riqueza e status, podemos argumentar que a "acomodação evolutiva", ao mesmo tempo que incorporava segmentos de pequenos recursos - criando a perspectiva da mobilidade - hierarquizava a partir de uma nova estratificação social. De outro modo, as grandes posses de escravos, geralmente associadas às regiões e atividades com maior tendência à mercantilização de seus produtos, bem como à estratégia da diversificação do capital no interior das próprias unidades produtivas, revelaram-se mecanismos garantidores do lucro e da distinção que, apesar de pulverizados pela sociedade mineira oitocentista, continuaram legando as melhores chances de inversão, apropriação e usufruto da riqueza a uma minoria: aqueles proprietários que conseguiram acumular condições de poder econômico e político - afirmando-se como "elites" -, em relação a outros, reclassificados em escalas hierárquicas inferiores.

A confirmação destas considerações demanda uma análise mais verticalizada acerca dos demais itens constantes da composição das fortunas destes inventariados, bem como das atividades classificadas como "urbanas", conforme passaremos a averiguar.

IGLÉSIAS, Francisco. Periodização da História de Minas. Revista Brasileira de Estudos Politicos, N.29, p.192, julho de 1970; Idem. Política Econômica do Governo Provincial Mineiro (1835-1889). Rio de Janeiro: Instituto Nacional do Livro, 1958. p.61-62. 44

0 que não significa que a mineração tenha deixado de ser atividade produtiva largamente praticada, assim como tenha convivido, mesmo na sua fase áurea, com as atividades agropastoris, nas diversas partes das Minas.(Ver: PAIVA, Clotilde A.; BOTELHO, Tarcísio Rodrigues. A população e o espaço no século XIX mineiro: algumas evidências de dinâmicas diferenciadas. In: VII Seminário sobre a Economia Mineira. Belo Horizonte: CEDEPLAR/UFMG, 1995, vol.1. p.99).

45

Para efeitos de classificação, todos os inventários que não apresentaram qualquer menção a atividades produtivas do tipo (agricultura, pecuária, agropecuária, mineração) e não descrevia o logradouro do inventariado como sendo "fazendas, sítios, chácaras", foram classificados como "urbanos".

\section{Atividades econômicas e estratégias de distinção no universo urbano}

A "inflexão agrícola" que se seguira ao período auge minerador, estendendo-se por toda a cronologia de 1770 a 183143 , caracterizara-se não só pelo afloramento das atividades alternativas acima destacadas, com tendência à mercantilização 44 , mas pela maior pujança conferida ao universo rural, onde passaram a se concentrar as maiores chances de valorização do capital, seja pela disponibilidade de terras férteis para o cultivo dos gêneros de subsistência comercializados, seja pelas grandes extensões de "terras de criação". Ainda que a delimitação entre o universo rural e urbano não seja muito nítida, no contexto observado 45 , vale observar os dados extraídos do esforço de classificação das atividades econômicas desenvolvidas em cada um deles.

Assim, comparando o monte-mor médio dos inventariados classificados como urbanos, vis-à-vis aqueles classificados como unidades produtivas (Up's) e mistos, chegou-se à seguinte sistematização: 
PAIVA, Clotilde A. População e Economia nas Minas Gerais do Século XIX. Tese (Doutorado). São Paulo: Universidade de São Paulo, Depto de História, 1996. p.115.

47

ANDRADE, Francisco Eduardo. "A enxada complexa: roceiros e fazendeiros em Minas Gerais na primeira metade do século XIX". Dissertação (Mestrado). Universidade Federal Minas Gerais, Belo Horizonte, 1994.

48

É o caso da inventariada Ana Gonçalves de Oliveira, domiciliada em Água Limpa, Freguesia de Antônio Dias, Termo de Ouro Preto, proprietária de 2 "moradas de casa" na mesma localidade, e 1 na "Estrada que segue para Mariana", avaliadas em 110\$000 réis, sendo que esta última é descrita como possuindo seu "pequeno terreiro e com sua mina anexa". 0 fato de constarem dentre seus bens vários instrumentos utilizados na mineração - 1 "alavanca" e 3 "brocas de ferro", "marretas", 2 "almocafres já usados", "brocas" e "cunhas" do mesmo metal - confirmam que a principal atividade da inventariada era a mineração, embora classificada como propriedade "urbana". (Inventário post mortem de Ana Gonçalves de Oliveira. (CPOP, cód. 38, auto 425, $2^{\circ}$. Of., ano de 1823).

49

FURTADO, Júnia F.. O Livro de Capa Verde. 0 Regimento diamantino de 1771 e a vida no Distrito Diamantino no periodo da Real Extração. São Paulo: Annablume, 1996. p.47.

50

Esta classificação ocupacional baseou-se na forma de participação do indivíduo no mercado: comércio/rentismo (caso de lojas e vendas, bastante freqüentes; comércio ambulante; aluguel de casas ou juros sobre empréstimos ou aplicações) e indústria doméstica/ artesanato (predominando aqui as atividades têxtil, sapataria, carpintaria, alfaiataria, marcenaria, funilaria ou "ferreiro"). Aqui também fizemos questão de destacar os casos em que o inventariado possui alguma patente militar ou cargo público (geralmente vivendo de seus soldos e salários, mas podendo conjugar alguma outra atividade), a fim de atestarmos para o peso destas ocupações em cada localidade. De qualquer modo, vale frisar, a classificação como "unidade produtiva" não inviabiliza a presença de comércio, indústria doméstica ou patente militar, tendo havido a preocupação em desdobrar um mesmo inventário em mais de uma categoria. Por fim, aqueles inventários que combinam atividade predominantemente urbana com unidades produtivas, foram classificados separadamente como "mistos". Para situar a posição social dos indivíduos empregados nestas diversas profissões, além das funções coevas a elas atribuidas, utilizamos, as seguintes referências: SILVA, Antonio Morais. Dicionário da Lingua Portuguesa Composto pelo Padre Rafael Bluteau, reformado e acrescentado por Antonio de Moraes Silva. Lisboa: Oficina de Simão Tadeu Ferreira, 1789 (4a. Ed, 1831); GODOY, Marcelo Magalhães.Dicionário das Ocupações em Minas Gerais no Século XIX, acompanhado de estudo histórico em torno da economia e sociedade mineira provincial. In: Revista Varia História, n. 15, p.161-192, março de 1996.

Considerou-se aqui tanto as atividades desenvolvidas por proprietários urbanos, passiveis de identificação, quanto aquelas desenvolvidas por unidades mistas, elegendo-se aqui apenas a atividade desenvolvida no imóvel urbano.

\begin{tabular}{|c|c|c|}
\hline Localidade & Monte médio das Up's e mistos & Monte médio Urbano \\
\hline Ouro Preto & 325,38 & 592,5 \\
\hline São João & 1955,26 & 946,0 \\
\hline Distrito & 689,86 & 641,84 \\
\hline Paracatu & 275,50 & 244,31 \\
\hline
\end{tabular}

Com exceção do Termo de Ouro Preto, a riqueza média é flagrantemente superior nas unidades produtivas. É possivel que a situação só não se confirme para o caso ouropretano em função de três motivos que nos parecem pertinente considerar.

Primeiramente, o fato de estarmos considerando um recorte espacial limitado às localidades situadas na principal área mineradora da Comarca de Vila Rica, não levando em conta aquelas provavelmente mais propícias ao desenvolvimento da agropecuária, situadas mais ao sul da região 46 , com maiores chances de obter êxito neste setor, no período analisado. A exemplo do esforço empreendido por Francisco Andrade - o qual, em recente estudo, focaliza as especializações distritais da região, com ênfase no Termo de Mariana, concluindo acerca das implicações do meio geográfico, da maior ou menor devastação do solo provocada durante o periodo minerador, sobre as possibilidades da agropecuária ${ }^{47}$ - , a confirmação desta hipótese exigiria um estudo detalhado acerca da distribuição ocupacional pelos distritos e freguesias da Comarca, o que foge às dimensões desta pesquisa.

Em segundo lugar, é preciso considerar que muitos inventários classificados como urbanos podem estar envolvidos com alguma atividade agropecuária, ou mesmo mineratória 48 . Por fim, não se pode desprezar o fato de que Ouro Preto era a sede administrativa da província, sendo natural haver aí uma vida urbana mais dinâmica e o forte peso de um funcionalismo público, estimulando e sofisticando o consumo local. Este último aspecto é comum ainda à região do Distrito, onde o "estreitamento das relações de interesse que foi se consolidando entre a população local e a Real Extração com a ocupação de cargos administrativos e policiais"49 tornou, desde finais do XVIII, expressivo o papel deste funcionalismo no incremento do consumo e dinamismo da vida urbana.

0 gráfico abaixo oferece uma noção dos tipos de atividades urbanas predominantes em cada localidade 50 :

Tipos de atividades em meio urbano, por localidade ${ }^{51}$




PAIVA, Clotilde A. População e Economia nas Minas Gerais do Século XIX. Tese (Doutorado). São Paulo: Universidade de São Paulo, Depto de História, 1996. p.83.

53

Ao tratar das especificidades do comércio mineiro setecentista e seus principais atores, Cláudia Chaves divide-os em dois grupos: os que eram abastecidos pelos mercados do Rio de Janeiro, São Paulo e produtores rurais de Minas Gerais (os "tropeiros", "atravessadores", "mascates", "boiadeiros", "negras de tabuleiro") e os que compravam e revendiam mercadorias em seus estabelecimentos fixos ("vendeiros", "lojistas" e "comissários"). (CHAVES, Cláudia Maria das Graças. Perfeitos negociantes: mercadores das Minas setecentistas. Dissertação (Mestrado). Universidade Federal de Minas Gerais, Belo Horizonte, 1995. p.49).

54

Ibidem

55

Inventário post mortem deThomé Gonçalves (BAT, maço $68,1^{\circ}$. Of. Ano de 1822).

56

Em estudo baseado nos livros de licenças municipais concedidas aos estabelecimentos comerciais, oficinas, edificações de residências, atividades públicas religiosas e de entretenimento, Graça Filho identifica, para a Vila sanjoanense, 190 licenças para estabelecimentos comerciais em 1830, 224 licenças em 1831 e 195 licenças para o ano de 1832, sendo que o maior número corresponde às vendas (37 registros) e lojas (127 registros). (GRAÇA FILHO, Afonso Alencastro. A Princesa do Oeste e o Mito da Decadência de Minas Gerais. São João Del Rei (1831-1888). São Paulo: Annablume, 2002. p.60-61). 57

PAIVA, Eduardo França. Escravos e Libertos nas Minas Gerais do século XVIII. Estratégias de resistência através dos testamento. 2a. Ed. São Paulo: Annablume, 1995. p.167. Em nossa amostragem, é esta a situação de Lucas José de Araújo, morador na Vila de Ouro Preto, proprietário de "uma morada de casas de pedra (...) com suas lojas pelos fundos, com seu grande quintal, com quartéis de capim, arvoredos, de frutas, laranjeiras, pessegueiros, limoeiros, cafezais, bananal, murado tudo de pedra arada".(Inventário post mortem de Lucas José de Araújo - CPOP, cód. 32, auto 356, 2. Of., ano de 1829).

58

Inventário post mortem de João Antônio Duarte (CPOP, cód. 30, auto 341, ano 1821).

59

Em São João Del Rei, o inventário do Advogado Gomes da Silva Pereira nos dá outra amostra da sofisticação do consumo e dos vinculos comerciais com outras provincias. Dentre seus bens descreve "couro curtido" - geralmente importado da região de Paracatu e Minas Novas -; 4 "pratos brancos do Porto"; 1 "estojo com duas navalhas e pedra"; 5 "pratos azuis finos"; 3 "pratos azuis pó de pedra"; 1 ferragem dourada para cômoda"1 "prato de louça do Porto"; 1 "tigela com seu prato fino da Índia"; 1 "garrafinha branca"; 5 "garrafas pretas"; 1 "resma de papel ordinário"; 1 "balança de pesar ouro com seu marco e pesos"; 1 "fechadura inglea"; 1 "relógio com sua corrente de ouro"; 13 "toalhas de mãos de algodão"; lençóis e fronhas de "Bretanha"; 14 "camisas de bertanha"; 3 "varas de algodão furtão da
Os estabelecimentos comerciais urbanos mais comuns nas Minas oitocentistas eram as vendas (de menor porte, distribuídas pelas áreas urbanas e estradas, especializadas em aguardente e molhados), as lojas e armazéns (com uma maior diversificação de gêneros, incluindo os importados, ferragens, remédios, etc, situadas geralmente nos núcleos urbanos maiores) ${ }^{52}$. Apesar de difundida por todas as localidades observadas, o perfil e abrangência desta rede comercial variou em cada uma delas segundo os produtos e épocas, havendo uma significativa diferença entre aqueles artigos que atravessavam os registros para serem comercializados nas Vilas, a varejo, e os que ai eram ordinariamente comercializados, provindos de sitiantes menores, situados nos arredores das grandes Vilas e que não precisavam atravessar nenhum posto fiscal, não sendo onerados com impostos. 53

Além desta diversidade de situações, a atividade fiscal dos Registros desmente a idéia de que haveria comércio especializado para cada mercadoria, havendo antes um grande número de pequenos comerciantes eventuais, não especializados, combinando uma hierarquia econômicosocial diferenciada, com uma estrutura mercantil pré-capitalista. ${ }^{54}$

Esta marca da "não especialização" do comércio mineiro parece ter adentrado o século XIX, refletindo-se na diversidade dos produtos estocados nos estabelecimentos urbanos, conforme comprovado pela amostragem selecionada ${ }^{55}$. Além disso, há uma visivel assimetria entre as regiões analisadas no concernente ao dinamismo e concentração destes estabelecimentos comerciais, marcadamente mais sofisticados quanto à diversidade e natureza dos produtos quando se tratam de estabelecimento situados nas regiões Mineradora Central Oeste (onde se situam Ouro Preto e o Distrito Diamantino) e Sudeste (onde se localiza a Vila de São João Del Rei).

Esta última, além de constituir-se em entreposto com o Rio de Janeiro, sustentava um pequeno comércio intra-regional de víveres provenientes tanto dos arredores, quanto da região intermediária de Pitangui-Tamanduá, Minas Novas e Paracatu, destacando-se nestes casos o comércio de gado, couro e algodão, conforme já referido. Apesar de raramente os estabelecimentos comerciais virem descritos como lojas ou vendas - o que dificulta uma categorização mais apurada56 - e do fato comum do espaço da casa servir não só como habitação, mas alguns cômodos serem transformados em venda de secos e molhados ${ }^{57}$, tais informações, quando passiveis de serem inferidas a partir dos objetos descritos nos bens dos inventariados 58 , esclarecem ainda acerca das redes mercantis nas quais os comerciantes de cada região estavam inseridos. 59

Em alguns casos, os objetos arrolados sugerem que parte do que era vendido nestes estabelecimentos comerciais provinha da "indústria doméstica", predominando as seguintes atividades artesanais, em cada região: em Ouro Preto e no Distrito, 4 de sapataria60, 3 de alfaiataria61, 4 carpintaria e marcenaria $62 ; 1$ barbeiro ${ }^{63}, 4$ ferreiros $^{64}$ e 4 tecelagens ${ }^{65}$; para São João Del Rei a fiação e tecelagem (as quais aparecem em 5 dos 6 inventários urbanos com indústria doméstica) ${ }^{66}$, seguida pela alfaiataria (apenas 1 caso na amostragem analisada)67, sapataria (também 1 caso)68, e ourivesaria. 69

A situação das localidades descritas contrasta enormemente com a do Termo paracatuense, onde tanto os estabelecimentos comerciais 
terra"; 2 "varas de fita para travesseiro"; 1 "boldrie de fagote obra da terra". É assim que, dos objetos acima descritos, os artigos de cobre, "folhas de flandres" - utilizadas na atividade de latoeiro -, artigos de luxo - como as louças do Porto -, sugerindo vínculos com a praça mercantil do Rio de Janeiro, os quais se mostraram muito mais intensos nos Termos de Ouro Preto, São João e no Distrito, que na distante Paracatu. (Inventário post mortem do Dr. João Felisberto do Couto, MRSJDR, cx 70, ano de 1808). 60

Inventários post mortem de Lucas José de Araújo, op. cit.; João Antônio Duarte (CPOP, cód. 30, auto 341, ano 1821); Mauricio Jose de Jesus (BAT, maço $62,1^{\circ}$, ano 1821); Jerônimo José de Valladares (BAT, maço 34, $1^{\circ}$. Of., ano 1808); Bernardo Antônio da Roxa (BAT, maço $11,1^{\circ}$. Of., ano 1810).

61

Inventários post mortem de Mauricio Jose de Jesus (BAT, maço 62, 1‥ Of., ano de 1821); Antonio Ramos da Silveira (BAT, maço 166, $2^{\circ}$. Of., ano 1830); João Antônio Duarte (CPOP, cód. 30, auto $3412^{\circ}$. Of., 1821).

62

Inventários post mortem de José Rodrigues Pombo (CPOP, cód. 20, auto 208, 2. Of., 1823); Antonio Marques dos Santos(CPOP, cód. 04, auto 40, $2^{\circ}$. Of., 1821); Manoel Gomes (BAT, maço 56, 1‥ Of., ano de 1831); Henrique da Costa Silva (BAT, maço $190,2^{\circ}$. Of., ano 1822).

63

Inventário post mortem de João Antonio Duarte(CPOP, cód. 30, auto $3412^{\circ}$. Of., 1821).

64

Inventários post mortem de Antônio José de Sousa (CPOP, cod. 66, auto 76, 2. Of., ano 1823); Manoel da Rocha (CPOP, cod. 42 , auto 475, $2^{\circ}$. Of., ano 1831); José Joaquim de Castro (CPOP, cod. 29, auto 325, 2. Of., 1829); Antônia Pereira dos Santos (CPOP, cod. 57, auto 640, 20. of., 1823).

65

Inventários post mortem de João Gomes Carneiro (CPOP, cod. 26, auto 283, 2. Of., ano 1830); Antônio Marques dos Santos(CPOP, cód. 04, auto 40, 2. Of., 1821); Maria Moreira Só (BAT, maço 212, $2^{\circ}$. If., ano 1820); Caetano de Azevedo Coutinho (BAT, maço $14,1^{\circ}$. Of., ano 1829).

66

Inventários post mortem de Antônia Maria de Jesus (MRSJDR, cx. 111, ano 1822); João da Silva Machado (MRSJDR, cx. 356, ano de 1831); Quitéria Maria da Fonseca (MRSJDR, cx. 12, ano de 1792); Rita Felícia (MRSDR, cx 200, ano 1822); Maria Joana de Nazaré (cx. 176, ano de 1831).

67

Inventário post mortem de Cláudio da Silva Porto (MRSDR, cx. 313, ano de 1822).

68

Inventário post mortem de Mathias Gonçalves de Araújo Campo (MRSJDR, cx 475, ano de 1831).

69

Inventário post mortem do Tenente Coronel Joaquim José de Siqueira e Rita Pereira Tinoco. (MRSJDR, cx 276, ano de 1831).

70

Inventários post mortem de Victoria Batista da Silva (APM0G, cx/ano 1823); Maria Joaquina de Oliveira (APM0G, cx/ano de 1823); Antônio da Costa Carlos (APMOG, cx/ano de 1831).

71

SAINT-HILAIRE, Auguste de. Viagem pelo distrito dos diamantes e Litoral do Brasil. Belo Horizonte/ São Paulo: Itatiaia/Edusp, 1974. p. 119. urbanos, quanto as atividades artesanais pareceram inexpressivos, segundo dados de nossa amostragem ${ }^{70}$.

A despeito de opiniões contrárias de testemunhas coevas - como é o caso do viajante Saint-Hilaire, que constatara em Paracatu a existência de "um número considerável de botequins, bem como várias lojas com razoável sortimento de mercadorias" que os comerciantes "mandavam buscar em S. João Del Rei", enviando em troca "couros crus e algodão"71 - é possivel que tal quadro esteja refletindo a situação identificada por Paiva: o fato de que a dependência dos comerciantes de Paracatu em relação à praça mercantil sanjoanense limitava as possibilidades de acumulação de capital na região, implicando que, apesar do passado minerador muito mais recente, a opulência do ouro fosse aí uma formulação não só idealizada da economia aurifera ${ }^{72}$, como extremamente efêmera e restrita à minoria de proprietários que controlavam o comércio de longa distância - particularmente o do gado -, que além de constituir o gênero mais rentável e menos sazonal, comercializado nas Minas e interligado aos mercados das capitanias vizinhas, implicava controle do espaço e, portanto, poder. ${ }^{73}$

Se as assimetrias regionais e sociais, traduzidas em categorias e abrangências também diferenciadas das rotas mercantis, têm importância decisiva do ponto de vista das redes de solidariedade e alianças políticas desenvolvidas entre os segmentos nelas envolvidos - pois, durante todo o século XVIII e boa parte do XIX, o mercado permaneceu com o duplo aspecto de nexo social e econômico, sendo o lugar onde eram realizadas as transações comerciais e pessoais, permitindo a ampliação das redes clientelares daqueles que dominavam este ramo - a situação adensa-se quando agregamos ao controle do comércio, a atividade prestamista.

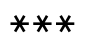

0 "viver de juros" - tanto pela aplicação do dinheiro, quanto, e principalmente, pela atividade prestamista - era prática corrente nas Minas de finais do XVIII e inícios do XIX, reflexo da baixa liquidez e pequena circulação monetária caracteristica da economia colonial74, em especial das regiões de mercado restrito, mas que não esteve ausente nem mesmo no Rio de Janeiro, centro econômico e político do sudeste brasileiro ${ }^{75}$. Esta realidade se traduz na significativa participação das dívidas ativas que, juntamente com os escravos e os imóveis, compunham o grosso do patrimônio dos inventariados mineiros, conforme revela o gráfico abaixo:

Participação percentual dos ativos no patrimônio total

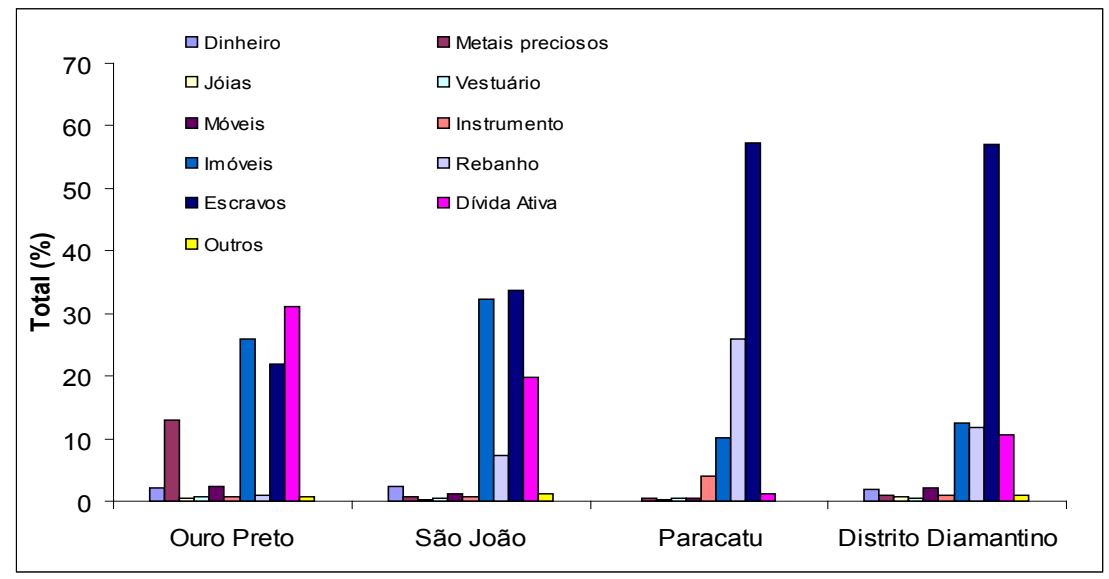


Argumento que, de resto, vem sendo confirmado a partir do universo material revelado pelos próprios antigos núcleos mineradores. (Ver: FRIEIRO, Eduardo. O diabo na livraria do Cônego. Belo Horizonte:1957. p164, apud: ALMEIDA, Carla Maria C. de. Ricos e pobres em Minas setecentistas: uma sociedade colonial polarizada. Oficina da Inconfidência. Revista de Trabalho. Ouro Preto: Museu da Inconfidência, ano 4, N.3, p.136, dez/2004.

73

CHAVES, Cláudia Maria das Graças. Perfeitos negociantes: mercadores das Minas setecentistas. Dissertação (Mestrado). Universidade Federal de Minas Gerais, Belo Horizonte, 1995. p.113-121. 74

Amaro Cavalcanti estima que, à época da transferência da Corte para a América Portuguesa, não passava de 9 a 10 mil contos todo o numerário do pais, sendo $2 / 3$ em ouro e $1 / 3 \mathrm{em}$ prata. 0 cobre era em pequena quantidade, estando seu poder liberatório limitado a 100 réis. (apud. SIMONSEN, Roberto. História Econômica do Brasil (1500/1820) 6. Ed., p. 406).

75

FRAGOSO, João Luis Ribeiro. Homens de grossa aventura: acumulação e hierarquia na praça mercantil do Rio de Janeiro (1790-1830). Rio de Janeiro: Civilização Brasileira, 1998. p.254-255.

76

SILVEIRA, Marco Antonio. 0 universo do indistinto. Estado e sociedade nas Minas setecentistas (17351808). São Paulo: Hucitec, 1997.

77

Um fato que pode ter contribuido para a redução do peso das dividas após 1822 foi a instalação de uma filial do Banco do Brasil na Vila de São João, com autorização para imprimir papel moeda, o que talvez justifique o módico aumento deste meio circulante no total da riqueza dos inventariados 1,54\% para 3,83\%. Além disso, é possivel considerar a tendência observada para toda a Comarca, conforme estudo de Carla Almeida, a qual constada que, do periodo de 1750-1779 para o de 1780-1822, houve uma sensivel queda no grau de participação das dividas entre os proprietários do Rio das Mortes, assim como os de Vila Rica, fruto da maior valorização dos bens imóveis, no primeiro caso, e, em ambos, à maior concentração do crédito. (ALMEIDA, Carla Maria C. de. Homens ricos, homens bons: produção e hierarquização social em Minas colonial (17501822). Tese (Doutorado em História). Rio de Janeiro: Universidade Federal Fluminense, 2001. p.129).

78

0 maior peso das dividas ativas no total das fortunas para o ano de $1792(62,36 \%)$, deve-se ao peso de 1 dos inventários, no qual este ativo assume 0 valor de 1.872 libras, equivalente a $96,8 \%$ do total das dividas ativas do periodo. Logo, não se pode tomar a queda na participação percentual das dividas ativas no total das fortunas de 1792 para 1808 como representativa de uma tendência mais geral, 0 que deverá ser apurado pela finalização da pesquisa, com complementação da amostragem selecionada. 79

GRACA FILHO, Afonso Alencastro. A Princesa do Oeste e o Mito da Decadência de Minas Gerais. São João Del Rei (1831-1888). São Paulo: Annablume, 2002. p.72.

80

SEIDLER, Carl. Dez anos de Brasil. Belo Horizonte/ São Paulo: Itatiaia/Edusp, 1980. p. 302. (Apud. GRAÇA FILHO, Afonso Alencastro. Op.Cit., p.75).
Segundo dados da amostragem analisada, o percentual de dinheiro sobre o total da riqueza dos inventariados varia, para toda a cronologia recortada, entre 0,23\% (caso de Paracatu, no sub-periodo de 1822) e módicos 4,95\% (caso do Distrito Diamantino, na conjuntura de 182931). Além disso, este ativo se encontra concentrado em poucas mãos: 0 total da moeda para todo o período (aproximadamente, 6.138,45 libras) era detido por apenas $16,5 \%$ do total de proprietários, dos quais, 59,4\% pertenciam a São João Del Rei, quadro que atribuímos ao seu comércio mais ativo, implicando maior circulação de moeda.

Tal situação confirma o quadro descrito por Silveira: "na falta do ouro - ou mesmo articulando-se a ele -, as trocas estabeleceram-se em razão das promessas e empenhos de palavra, fossem ou não embasados em papéis escritos. 0 fiado e a divida eram generalizados"76, constatação que adentra o século XIX, impondo alguns breves comentários a respeito do perfil do sistema creditício nas localidades observadas.

Partiremos do caso sanjoanense, onde o peso das dívidas ativas parece ter atingido maiores montantes e constância durante os sub-períodos recortados - exceção feita à conjuntura de $1831^{77}$-, fato que deve ser atribuído não apenas à crônica restrição de numerário, acima referida, mas ao alto comércio aí reinante, dinamizado principalmente a partir de 180878 , que "transmutava a praça mercantil de São João em centro financeiro para uma ampla região de Minas Gerais".79

Controlado pelas famílias mais abastadas da região, o crédito significava, além de importante fonte de renda, prestígio social, justificando o comentário oficial do mercenário a serviço de D. Pedro I - Carl Seidler -, durante sua segunda viagem a Minas, em 1830, segundo o qual, a influência dos "portugueses natos" sobre a população da província era notória, "pois que quase todos os moradores do interior devem aos negociantes de São João e por isso em muitos sentidos Ihes são sujeitos". 80

Esta realidade se confirma pelo perfil dos inventariados que, para cada sub-periodo, concentravam o maior montante de dividas ativas. Grosso modo, tratavam-se de portugueses, naturais da região de Braga e donos de estabelecimentos comerciais ${ }^{81}$. Perfil semelhante parece caracterizar os maiores credores do Termo ouropretano, diferindo apenas a principal atividade por eles praticada: em geral, são detentores de patentes militares, vivendo de soldos 82 . No Distrito Diamantino $40 \%$ dos credores eram comerciantes, sendo os dois maiores também naturais de Braga, e o terceiro maior de naturalidade desconhecida.

Com relação a Paracatu, única região em que o peso das dívidas ativas se revelou infimo em comparação a outros ativos - fato que atribuímos não só ao menor dinamismo de sua praça mercantil, mas também à já mencionada dependência de seus comerciantes em relação aos de São João, junto aos quais provavelmente se endividavam 83 -, os três únicos credores de nossa amostragem confirmam a tendência à concentração do referido ativo nas mãos dos proprietários vinculados ao setor mais dinâmico da região: eram fazendeiros e comercializavam gado84, ramo de atividade que, conforme já mencionado, configurava-se no mais lucrativo e menos sazonal do comércio de longa distância.

A situação desta região distoa das demais ainda num outro aspecto: apesar de nossa amostra só contar com 3 credores paracatuenses, observa-se que o montante de dividas ativas está distribuído entre eles de forma relativamente eqüitativa. Em outros termos, tratam-se de 
São os casos de 2 dos maiores credores de nossa amostragem: o Capitão Antônio Gonçalves Barbosa, com total de dívidas ativas no valor de $6: 119 \$ 525,75$ réis, distribuidos entre 83 devedores e representando nada menos que $68 \%$ do total de sua riqueza; Dr. João Felisberto do Couto, cujas dívidas ativas totalizavam 4:660\$357 contos de réis, distribuídas entre 97 devedores, equivalendo a 83\% do total de sua fortuna. (Inventário post mortem do Capitão Gonçalves Barbosa (MRSJ, cx. 70, 1792); Inventário post mortem do Dr. Felisberto do Couto (MRSJDR, cx 323, 1808)).

82

Inventários post mortem de Marçal José de Araújo (CPOP, cód. 36, auto 400, ano de 1819) e Matias Sanches Brandão (CPOP, cód., 95, auto 1169, $2^{\circ}$. Of. 1793).

83

Infelizmente, na descrição das dívidas passivas dos proprietários paracatuenses, não foi possivel identificar a região onde foram contraidos os débitos, constando apenas o nome do credor. De qualquer forma, em leitura mais apurada, procuraremos fazer o cruzamento das informações e das fontes, a fim de apurarmos tal argumento.

84

Inventários pos mortem de Lázaro Lopes da Silva (APM0G, cx/ano de 1794); Melchior José de

Magalhães (APMOG, cx/ano 1822); Caetano José Sol (APMOG, cx/ano 1822).

85

0 valor total das dividas ativas distribuidas entre os 34 credores de Paracatu é de apenas $59 \$ 425$ réis. Logo, um valor médio de $19 \$ 808$ réis.

86

Neste caso, foi excluído o inventário de Antonia Maria Custódia Dias, cujo valor muito elevado das dividas ativas poderia enviezar a análise. Mesmo assim, a concentração deste ativo se mostra elevada.

87

Tratava-se de prática tradicional da Monarquia portuguesa, no sentido de conquistar lealdade dos súditos e retribuir serviços prestados ao rei, estando na base da formação de uma "nobreza da terra", comum a outras partes do Império ultramarino, sendo perpetuada a partir da instalação da Corte no Rio de Janeiro e ativada no momento da ruptura luso-brasileira. 0 percurso de D. Pedro I pelas diversas fazendas e Vilas mineiras ligadas ao comércio de abastecimento do mercado carioca, em 1822, revelava uma adesão negociada, na qual contaram para além do status e benfeitorias materiais conferidos aos proprietários contemplados por sua visita, os agraciamentos com cargos e promoções. (MONTEIRO, Nuno G. 0 ethos nobiliárquico. Almanack Braziliense, São Paulo, n. 2, out/ 2005; ver ainda: "Decreto"de 19 de Abril de 1822, por Estevão Ribeiro de Rezende, in: RAPM, ano 1909, vol. XIV, p. 405).

88

Da amostragem selecionada, o inventário com maior valor de dividas ativas é o de Antônia Maria Custódia Dias, casada, moradora na Vila de São João, com naturalidade não registrada, falecida em $03 / 01 / 1819$. Proprietária de alguns poucos móveis e utensílios domésticos, 6 porcos, 1 poltro, 1 mula cega e 10 escravos no valor de 1:020\$000 réis, a principal fonte de renda desta rica inventariada parecia provir da arrematação de alguns ofícios, como o de órfãos, tabelionato e ouvidoria, que provavelmente funcionavam em prédios também de pequenos créditos, distribuidos entre poucos credores 85 , enquanto nos demais Termos é flagrante o elevado grau de concentração deste ativo, característica que se acentua no caso sanjoanense, conforme revelado pelos percentuais abaixo:

Concentração das dívidas ativas, por localidade

\begin{tabular}{|c|c|c|c|}
\cline { 2 - 4 } \multicolumn{1}{c|}{} & \multicolumn{3}{c|}{ Localidades } \\
\hline Dívidas & Ouro Preto & São João 86 & Distrito \\
\hline$\%$ proprietários & $18 \%$ & $22 \%$ & $25 \%$ \\
\hline$\%$ dívidas & $71 \%$ & $93 \%$ & $71,7 \%$ \\
\hline
\end{tabular}

Os inventários destacados revelam ainda outros aspectos singulares do sistema de endividamento em São João, passiveis de serem verificados nas demais localidades mineiras selecionadas. Por um lado, o fato de que, se o controle do crédito significava poder e prestígio social, geralmente ele vinha associado a outros mecanismos que atuavam neste mesmo sentido. Os mais freqüentes eram as patentes militares e o acesso a cargos que viabilizavam enriquecimento e ascendência junto a parcelas da sociedade ${ }^{87}$. Os três exemplos acima se encaixam em alguma destas situações e, se tomarmos o total de credores para todas as localidades estudadas, nos diferentes momentos, verificaremos que em 30\% dos casos a situação se confirma. 88

Neste sentido, é possivel afirmar que comércio, atividade prestamista e ostentação de patentes e títulos eram variáveis que caminhavam juntas no delineamento da hierarquização social nas Minas oitocentistas, reforçando-se e, muitas vezes, condicionando-se mutuamente, já que, seguindo interpretação de Graça Filho acerca da dinâmica mercantil em São João Del Rei, a "apropriação de capitais pelo comércio" tornava-se um dos caminhos para o enobrecimento de algumas familias 89 , ainda que restrito a pequenas localidades.

Em mais de um exemplo, há sobreposição destes mecanismos de obtenção do lucro e distinção, aos quais se agregavam os bens móveis mobiliários e utensilios domésticos -; vestuários e indumentárias - roupas, jóias, chapéus - e a prataria ${ }^{90}$. Este último ativo, vale frisar, constituía parte substancial das fortunas dos inventariados ouropretanos e do Distrito - representados pelos "arreios", "esporas", "espadas" e "talheres" de prata -, associando-se às vestimentas mais requintadas - as botas altas, chapéus, capas, "camisas de Bretanha" e "casimira", vestidos de setim e "veludilho" -, tendo um peso visivelmente menor nos bens dos sanjoanenses - exceção feita ao item vestuário, em função, possivelmente, das ricas indumentárias dos grandes fazendeiros ${ }^{91}$-, e quase insignificante nos dos paracatuenses. A tabela abaixo sistematiza estas informações:

Participação percentual dos metais, jóias e vestimentas nas fortunas dos inventariados

\begin{tabular}{|c|c|c|c|c|}
\cline { 2 - 5 } \multicolumn{1}{c|}{} & \multicolumn{4}{c|}{ Localidades } \\
\hline Dívidas & Ouro Preto & São João & Distrito & Paracatu \\
\hline METAIS & 12,5 & 0,6 & 1,1 & 0,4 \\
\hline JÓIAS & 2,3 & 0,1 & 0,6 & 0,2 \\
\hline VESTIMENTA & 2,3 & 0,2 & 0,5 & 0,4 \\
\hline
\end{tabular}


sua propriedade, já que entre seus bens imóveis eram avaliadas 3 "moradas de casas" na Vila de São João, no valor de 2:020\$000 réis. Apesar de contar com "uns chãos no Arraial de Matozinhos" avaliados em $250 \$ 000$ réis, era dos cargos arrematados que provinha a exorbitante quantia de 12:205 $\$ 222,5$ réis $(78 \%$ de sua riqueza total), creditada a nada menos que 793 devedores! (Inventário post mortem de Antônia Maria Custódia Dias (MRSDR, CX 301, 1822).

89

GRAÇA FILHO, Afonso Alencastro. A Princesa do Oeste e o Mito da Decadência de Minas Gerais. São João Del Rei (1831-1888). São Paulo: Annablume, 2002. p.65.

90

Inventário post mortem de Marcos José Rebelo. (CPOP, cód. 37, auto 410, $2^{\circ}$. Ofício, 1829). (grifo meu).

91

Esta parece ter sido uma tendência que aprofundou-se em outras regiões, durante o XIX, conforme estudo de Eduardo Schoor, para o Vale do Paraiba. (SCHOOR, Eduardo. Os senhores dos caminhos: a elite na transição para o século XIX. In: DEL PRIORE, Mary (org.). Revisão do Paraíso. Os brasileiros e o Estado em 500 anos de História. Rio de Janeiro: Campus, 2000. p. 164).

92

É esta a situação de Ritta Quitéria de São José Fernandes de Oliveira - a maior credora de nossa amostragem - a qual, apesar de um patrimônio avaliado em 12:567\$920 réis, possuía dividas passivas no valor de 27:973\$093 réis, distribuídas entre 8 credores, valor dos qual aproximadamente 14,18\% era composto pelos juros rolados. Ficando uma herdeira menor, filha do casal, sob "Pátrio poder", e "por se achar a herança tão onerada de dividas", o viúvo inventariante, Capitão Bento Dias Chaves, recorria ao juiz de órfãos, alegando não "ser perjuro", mas "assim como quando as dividas importam em mais do que os bens, se não deve fazer inventário (...), por esta mesma razão, se não deve também fazer uma partilha ilusória", uma vez que "as dividas passivas excedem muito o valor dos bens inventariados". (Testamento de Rita Quitéria de São José Fernandes de Oliveira, 1808. (BAT, maço 63, $1^{\circ}$. Ofício, ano de 1808).

93

SAINT-HILAIRE, Auguste de. Viagem pelas províncias do Rio de Janeiro e Minas Gerais. Belo Horizonte/São Paulo: Itatiaia/Edusp, 1975. p.291. 94

Conforme Graça Filho, muitas vezes implicava a lenta quitação por parte do devedor através da entrega de parte substancial de sua produção. 95

SILVEIRA, Marco Antonio. 0 universo do indistinto. Estado e sociedade nas Minas setecentistas (17351808). São Paulo: Hucitec, 1997.

96

É o que atesta o caso de Maria Custódia Dias credora, dentre outros, de 9 "crioulos" e "forros" - um deles alfaiate -, num montante de $125 \$ 405$ réis, ou seja, um valor médio de $13 \$ 933$ réis, superior a um padrão, que, segundo Graça Filho, raramente ultrapassava a casa dos $2 \$ 000$ réis. Mesmo aqueles crioulos que não aparecem descritos como forros, infere-se tal condição, pois quando se tratava da categoria escravo, o crédito vinha seguido pelo nome do senhor.(Inventário post mortem de Antônia Maria Custódia Dias (MRSDR, CX 301, 1822)).
Embora os dados acima não nos permitam concluir acerca do significado destas participações diferenciadas dos ativos em causa nas fortunas analisadas, é possível sugerir que, nos núcleos mineradores mais antigos, tais estratégias de distinção revelaram-se mais resistentes a transformações, permanecendo diretamente associadas aos objetos garantidores de "bom tratamento" mesmo após a crise mineradora.

Em nenhum dos casos, porém, a perspectiva do lucro esteve ausente dos cálculos de investimento daqueles proprietários. Pensando especificamente na atividade prestamista, observa-se que o montante de juros movimentado pelo capital usurário era bastante significativo e, embora não disponhamos de dados seriais que viabilizem a avaliação do desempenho desta variável no tempo, comparativamente a outros preços, alguns inventários analisados nos dão indícios acerca de sua rentabilidade, a começar pelo fato, não raro, de que o valor dos juros acrescidos ao principal das dívidas ativas e passivas dos inventariados, quando declarado, revela uma participação substancial no total das fortunas, a ponto de implicar, em muitos casos, na insolvência do devedor. ${ }^{92}$

Esta última situação esgarça algumas das tensões impostas por uma atividade perpassada por duas lógicas distintas, mas complementares: pelo lado do credor, a simultânea expectativa do lucro - já que, conforme observava Saint-Hilaire, "não quer desfazer-se de sua mercadoria senão por preços superiores ao seu valor real"93 - e da consideração social, garantias, privilégios e cumplicidades que esperava obter com a pulverização dos empréstimos; pelo lado do credor, a expectativa de aquisição de bens, muitos dos quais condição de obtenção de rentabilidade - quando se tratavam de mercadorias, instrumentos de trabalho, terras, escravos -, mas também de status, levando a uma forma de inversão do capital onde o retorno esperado estava longe de ser, para ambos os agentes, algo garantido. ${ }^{94}$

Finalmente, vale frisar a inestimável relevância das informações concernentes às mediações verticais impostas pelas dívidas, tornando ainda mais conflituoso, contraditório e imprevisível o cotidiano desta sociedade onde "todos tinham o que pagar e receber"95. Especificamente, chama a atenção o acesso ao crédito por aqueles elementos sociais subordinados, incluindo os egressos do cativeiro ${ }^{96}$, quando não os próprios escravos. ${ }^{97}$

Segundo Graça Filho, era comum o endividamento de escravos na Vila saojoanense, o que "deveria facilitar o exercício de profissões ao ganho por esses cativos" 98 . No caso dos forros, acreditamos que o acesso ao crédito acenava com a perspectiva da mobilidade social viabilizando, em muitos casos, a "acomodação evolutiva" promovida por essas atividades - alfaiates, ferreiros, barbeiros, carpinteiros, oleiros, conforme descrito anteriormente -, por eles exercidas em cativeiro e carregadas para a vida de libertos. Entretanto, revelando sua dupla face, ao mesmo tempo em que o sistema creditício representava condição de mobilidade e acomodação, criava um novo laço de dependência para com os credores - geralmente brancos e donos de escravos -, prenhe de virtualidades.

Além da composição de ativos observada, é importante verificar o peso dos bens imóveis para cada região analisada. Contrastando com o insignificante peso dos instrumentos de trabalho - fruto da facilidade de adquirir novas terras a custos baixos e oferta elástica e também barata de mão-de-obra, viabilizando a prática agrícola pelo método da derru- 
97

É o caso da inventariada Leonor Maria da

Conceição, falecida a 08/01/1821, cuja fortuna

- avaliada em $879 \$ 586$ réis, compostos prioritariamente por 5 escravos $(550 \$ 000)$ e uma quantia em dinheiro (100\$000) - constava de $77 \$ 756$ réis emprestados aos escravos Joaquim Congo e Joana Benguela. (Inventário post mortem de Leonor Maria da Conceição. (MRSJDR, cx. 466, 1822)).

98

GRAÇA FILHO, Afonso Alencastro. A Princesa do Oeste e o Mito da Decadência de Minas Gerais. São João Del Rei (1831-1888). São Paulo: Annablume, 2002. p.72.

99

João Fragoso demonstrou a racionalidade de tal prática, perfeitamente ajustada à racionalidade da época, focalizando a região da Paraiba do sul e, mais recentemente, mesma idéia é reforçada pelo estudo de Francisco Andrade, sobre Minas. (FRAGOSO, João. Sistemas Agrários em Paraiba do Sul: um estudo de relações não-capitalista de produção (1850-1920).

Dissertação (Mestrado). Universidade Federal do Rio de Janeiro, Rio de Janeiro, 1983.

100

Analisando a composição das fortunas para os proprietários da região do Rio das Mortes, Carla Almeida constata que do periodo de 1750-1779 para o de 1780-1822, o peso destes ativos subiu de $28,61 \%$ para $37,48 \%$ do patrimônio total. Já na Comarca de Vila Rica, onde as lavras perderam produtividade, teria havido uma relativa desvalorização deste item, passando de $28,64 \%$ no primeiro período, para $25,92 \%$ no segundo, relativamente ao total dos bens inventariados. (ALMEIDA, Carla Maria C. de. Ricos e Pobres em Minas setecentista: uma sociedade polarizada, Oficina da Inconfidencia. Revista de trabalho. Ouro Preto: Museu da Inconfidencia, ano 4, N.3, p. 126, dez/2004). 101

É o caso de Ana Gonçalves de Oliveira, anteriormente mencionada, proprietária de duas "moradas de casa" situadas no termo de Ouro Preto, uma delas descrita como possuindo um "pequeno terreiro com sua mina anexa", tudo avaliado em $110 \$ 000$ réis. (Inventário post mortem de Ana Gonçalves de Oliveira. (CPOP, cód. 38 , auto $425,2^{\circ}$. Of., ano de 1823)).

102

Fragoso, analisando inventários de negociantes do Rio de Janeiro, justifica os investimentos imobiliários urbanos pela instabilidade dos negócios mercantis, bem como pelo ideal enobrecedor, de fugir do mundo do trabalho. (FRAGOSO, João Luis Ribeiro. Homens de grossa aventura: acumulação e hierarquia na praça mercantil do Rio de Janeiro (17901830). Rio de Janeiro: Civilização Brasileira, 1998. p.105-109).

103

É o que sugere, por exemplo, o inventário do

Capitão João Benavides, morador na cidade de Ouro Preto, proprietário de 7 "casas de morada" na mesma localidade, todas vistas e avaliadas em 1:400 $\$ 000$ réis, representando $93,87 \%$ de sua fortuna total. No Distrito, é esta ainda uma das principais fontes de renda de Ana Moreira Só, natural do próprio arraial do Tejuco, solteira, a qual declara ter "um rendimento do aluguel das casas" para serem recebidos, no valor de $52 \$ 912$ réis". (Inventário post mortem de Ana Moreira Só (BAT, maço 6, 1ํ. Of., ano 1822). Ainda para o caso do Termo ouropretano, sugerem alugar imóveis os seguintes inventariados: Ana Gonçalves de Oliveira, proprietária bada e queima dos matos ${ }^{99}$ ou, na pecuária, o método extensivo -, os imóveis, juntamente com os escravos e as dívidas ativas, ocupam lugar de destaque nas fortunas dos inventariados.

No caso de São João Del Rei, apesar do significativo rebanho bovino, suíno e ovino, os imóveis revelam uma maior participação percentual na riqueza total dos inventariados, o que pode ser entendido como reflexo da dinamização da economia de produção de alimentos, que tornava as fazendas localizadas em terras mais propícias ao seu desenvolvimento cada vez mais valorizadas ${ }^{100}$. Mesmo entre os bens dos proprietários do Termo de Ouro Preto e do Distrito Diamantino, os imóveis mantêm significativa importância - chegando, no primeiro caso, a superar a participação percentual da escravaria nas fortunas totais - o que, em princípio, pode ser imputado a dois fatores.

Primeiramente, o fato de muitas vezes as lavras - que nestas regiões sempre tiveram um maior peso que no Termo de São João - serem avaliadas juntamente com os imóveis, dificultando a apuração da exata proporção destes ativos no total do patrimônio ${ }^{101}$. Além disso, contrariamente ao que pode sugerir, o investimento em bens imóveis não obedeceu a uma lógica puramente "aristocratizante"102, uma vez que, constituindo-se em parte considerável de inversão imobiliária urbana, principalmente nos centros mais dinâmicos, representava além de importante reserva de valor, a percepção de renda de aluguéis. ${ }^{103}$

Em seu estudo sobre os comerciantes de São João Del Rei, Graça Filho identifica uma soma aplicada em imóveis urbanos superior à aplicada em imóveis rurais, escravos, animais e nas roças, reconhecendo aí também uma lógica de diversificação de capital, distante de qualquer propósito de sacrificar o lucro em prol do enobrecimento ${ }^{104}$. 0 mesmo raciocínio se aplica à lógica que movia as aplicações em bens de raíz - "ranchos e fazendas" - e escravaria, tendo em vista que tal tendência acompanha o próprio deslocamento das atividades potencialmente mais lucrativas, dependentes de terras mais produtivas e concentradoras dos maiores plantéis. Daí, a nosso ver, a tendência constatada entre os comerciantes mineiros de tornarem-se grandes fazendeiros e escravistas, não significando uma mera reprodução do "ideal aristocratizante", aventada para o caso dos grandes mercadores do Rio de Janeiro. ${ }^{105}$

Vale ainda notar que, contrariamente às demais regiões estudadas, os bens imóveis adquirem um peso sensivelmente menor no patrimônio dos proprietários paracatuenses, principalmente quando comparados aos "rebanhos". Tal constatação corrobora, em boa medida, o argumento segundo o qual, nos "vastos territórios que todos nomeavam 'sertões' a riqueza não se media simplesmente pelas terras de que se esperavam providos rendimentos agrícolas e pelos escravos. As fortunas mediam-se também pelo número de cabeças de gado, vacum ou cavalar.106

\section{Considerações finais}

Ainda que o recorte documental analisado não nos permita afirmações conclusivas acerca das variáveis consideradas, esta breve incursão pelo diversificado universo material das Minas Gerais oitocentistas desvenda uma sociedade em flagrante processo de diferenciação das atividades 
de (CPOP, cód. 38, auto 425, 2. Of.,ano 1823) e Francisca Pulqueria Teodora de Sá (CPOP, cod. 11 auto $109,2^{\circ}$. Of., ano 823), ambas proprietárias de 3 imóveis urbanos, descritos como "casas de morada". 104

GRAÇA FILHO, Afonso Alencastro. A Princesa do Oeste e o Mito da Decadência de Minas Gerais. São João Del Rei (1831-1888). São Paulo: Annablume, 2002. p. 89-90.

105

Tal idéia é sugerida por Renato Pinto Venâncio, ao constatar tal tendência com base na análise de inventários e testamento. (VENÂNCIO, Renato Pinto. Comércio e Fronteira em Minas Gerais Colonial. In: FURTADO, Júnia F. Furtado (org.). Diálogos Oceânicos. Minas Gerais e as novas abordagens para uma História do Império Ultramarino Português. Belo Horizonte: Editoda da UFMG, 2001. p.187-197). 106

CARRARA, Ângelo Alves. Agricultura e pecuária na capitania de Minas Gerais (1674-1807). Tese, (Doutorado). Universidade Federal do Rio de Janeiro, Rio de Janeiro, 1997. p.159-160. Se tomarmos o gado bovino - sensivelmente predominante nos rebanhos da região - constataremos que o número médio de cabeças chega a 114 e, apesar de nossa amostragem reduzida, encontramos proprietários cujo rebanho equipara-se à média de animais entre os pecuaristas de Buenos Aires (790 cabeças) e do Rio Grande do Sul (995), nos respectivos periodos de 1751-1815 e 1765-1825. É o caso do fazendeiro José Joaquim de Mendonça Lima, que entre seus bens descrevia apenas a "fazenda de criar e plantar denominada Capão", onde morava com sua esposa e 3 filhas, alguns poucos instrumentos de agricultura (1 "machado velho", 1 "enxada velha", 1 "foice em bom uso", 1 "cavadeira velha"), 1 "ferro de marcar animais", 1 "serrote quebrado" e um considerável rebanho, composto por 800 "cabeças de gado de toda sorte", 200 "éguas de toda sorte", 5 "cavalos pastores de toda sorte", 5 "cavalos de custeio",18 "poltros de anno de toda sorte" e 1 "jumento", avaliados em 2:958\$000 réis, ou seja, 90,53\% de seu patrimônio total! (Inventário post mortem de José Joaquim de Mendonça Lima (APMG0, cx/ano de 1823)).

107

NOVAIS, Fernando Antonio. Condições de privacidade na colônia. In: História da Vida Privada no Brasil. Vol. 1, São Paulo: Cia das Letras. p. 30. 108

Tendência manifesta já pela lógica de composição das fortunas dos inconfidentes mineiros, conforme estudo de FURTADO, João Pinto. 0 manto de Penélope. História, Mito e Memória da Inconfidência Mineira de 1788-9. São Paulo: Cia das Letras, 2002. p.118. econômicas e do perfil demográfico, a qual, embora ainda marcada por forte conteúdo estamental - replicando padrões societários tipicamente Antigo Regime -, já introduzia valores e mecanismos de uma sociedade de classes, como o lucro e a mobilidade social, mormente nas regiões de produção fortemente mercantilizada. Situação que, reproduzindo e singularizando um perfil peculiar à sociedade colonial, adentra a fase da construção do Estado e da nação brasileiros aguçando, provavelmente, aquela "sensação de ambigüidade", pois que, simultaneamente, aproximava e distanciava as pessoas. 107

Se tal realidade sugere implicações diretas em termos das identidades coletivas que sustentaram alianças e projetos políticos alternativos, na passagem de "um Império a outro", em nível da composição das fortunas, das formas predominantes de inversão do capital, apropriação e usufruto da riqueza, desvendam-se percepções, motivações e experiências de homens movidos não apenas pelo desejo de preservar suas condições mais gerais de donos de terra e escravos - parâmetros básicos de ordenamento da vida e reprodução da condição senhorial, em colônia -, mas por uma "profunda atenção e sintonia com tendências econômicas locais e mundiais"108, a partir da qual formulavam avaliações realistas acerca das possibilidades mais lucrativas de seus investimentos, já que era através do próprio mercado que obtinham as condições de reprodução de um modo de vida aristocrático.

Até onde pudemos notar, tal avaliação orientava aqueles proprietários coevos no sentido da diversificação de seus capitais, seja no interior das unidades produtivas, com produções variadas e heterogênea composição dos rebanhos; seja no concernente à diversidade de produtos estocados nos estabelecimentos comerciais; seja na complexa teia social derivada do sistema creditício ou, ainda, na polivalente e concomitante atuação como comerciantes, funcionários públicos, militares, fazendeiros e rentistas. Um comportamento, a nosso ver, perfeitamente adaptado às situações de "crise" quando, à provisoriedade de formas, significados e das próprias opções de enriquecimento instaladas, os agentes estudados buscaram contrapor estratégias de diminuição dos riscos, garantia da estabilidade e preservação do status de proprietários e escravistas.

Em suma, mergulhados em realidades materiais diversas e em permanente transformação, atravessadas por acelerada - ainda que nem sempre sincronizada - erosão dos referenciais e padrões ordenadores da vida, em suas múltiplas dimensões, foram estas as estratégias distintamente disponiveis aos proprietários mineiros de finais do XVIII e inícios do XIX, no sentido de reinstaurarem os parâmetros garantidores de sua previsibilidade, preservando interesses econômicos e situações de poder muito concretos, que Ihes permitiram afirmarem-se como "elites".

Recebido para publicação em março de 2008 Aprovado em abril de 2008 